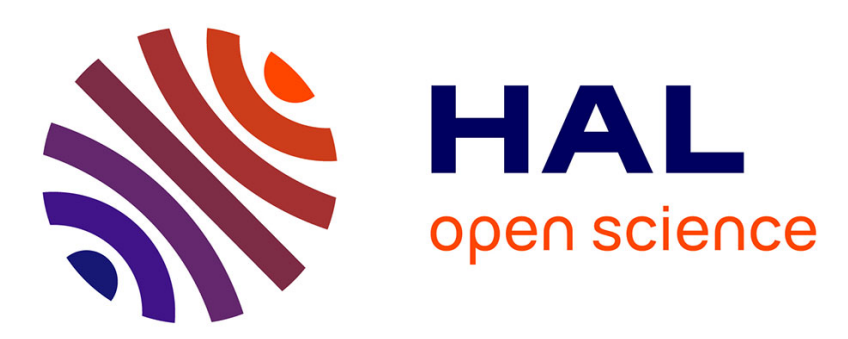

\title{
Agricultural benefits and environmental risks of soil fertilization with anaerobic digestates: a review Roger Nkoa
}

\section{To cite this version:}

Roger Nkoa. Agricultural benefits and environmental risks of soil fertilization with anaerobic digestates: a review. Agronomy for Sustainable Development, 2014, 34 (2), pp.473-492. 10.1007/s13593013-0196-z . hal-01234816

\section{HAL Id: hal-01234816 https://hal.science/hal-01234816}

Submitted on 27 Nov 2015

HAL is a multi-disciplinary open access archive for the deposit and dissemination of scientific research documents, whether they are published or not. The documents may come from teaching and research institutions in France or abroad, or from public or private research centers.
L'archive ouverte pluridisciplinaire HAL, est destinée au dépôt et à la diffusion de documents scientifiques de niveau recherche, publiés ou non, émanant des établissements d'enseignement et de recherche français ou étrangers, des laboratoires publics ou privés. 


\title{
Agricultural benefits and environmental risks of soil fertilization with anaerobic digestates: a review
}

\author{
Roger Nkoa
}

Accepted: 5 November 2013/Published online: 13 December 2013

(C) INRA and Springer-Verlag France 2013

\begin{abstract}
Intensive soil fertilization with mineral fertilizers has led to several issues such as high cost, nitrate pollution and loss of soil carbon. Fertilization with organic matter such as compost therefore represents an alternative for sustainable agriculture. Traditional organic amendments such as manures, composts and sewage sludge have been extensively studied in the past. However, applications of biogas digestates and their impacts on the environment and human health are still unexplored. Recent articles report the agricultural potential and conflicting results of digestate performances. As a consequence, the effectiveness of digestate as organic amendment and fertilizer is still under debate. Here we review the legislative, chemical, agronomic and environmental literature on anaerobic digestates. We found that digestates can be considered as organic amendments or organic fertilizers, when properly handled and managed. Indeed we further show that anaerobic digestates have a higher potential to harm the environment and human health than undigested animal manures and slurries. The main points are the following: (1) Most solid digestates comply with the European organic matter minimal requirement for an organic amendment; (2) the fertilizer values of liquid digestates lie between those of livestock manures and inorganic fertilizers; (3) anaerobic digestates have higher $\mathrm{NH}_{3}$ emission potential than undigested animal manures and slurries and, consequently, pose a greater risk to the broad environment; (4) high $\mathrm{Cu}$ and $\mathrm{Zn}$ concentrations in digestates from co-digestion of pig and cattle slurry feedstock could jeopardize the sustainability of agricultural soils and (5) high $\mathrm{Mn}$ concentrations in digestates can induce Mn toxicity in agricultural soils, upon repeated applications.
\end{abstract}

\footnotetext{
R. Nkoa $(\bowtie)$

University of Guelph, 50 Stone Road East, Guelph, ON, Canada N1G 2W1

e-mail: rnkoa@uoguelph.ca
}

Keywords Anaerobic digestate - Organic amendment · Organic fertilizer · Anaerobic digestion · Biogas residues

Content

Abstract................................................................... 1

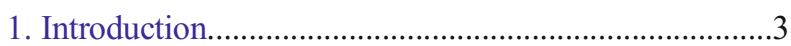

2. Digestates amending properties and effects on soil properties 6

3. Fertilizer properties and effects on crops.....................10

4. Environmental risks associated with land applications of anaerobic digestates...................................................16

5. Research needs......................................................27

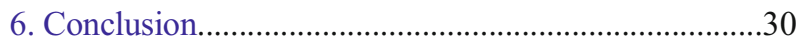

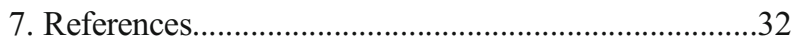

\section{Introduction}

The anaerobic digestion process, also termed biogas process or biomethanation, was highlighted for the first time in 1776 by Alessandro Volta (cited in Ahring 2003). Ever since, it has been utilized mainly for biogas production from animal manure and/or household wastes and for waste treatment (Angelidaki et al. 2003; Tani et al. 2006; Tambone et al. 2009). The popularity of the biogas process has grown since the 1970s, amidst rises of energy prices and worries about the detrimental impact of fossil fuels on global warming. Today, biomethanation has expanded significantly across the world, mainly in Europe where more than 4,000 farm-scale anaerobic bioreactors are found in Germany alone (Weiland 2010).

There are mainly seven lines of exploitation of anaerobic digestion: (a) treatment of municipal sewage sludge, (b) treatment of industrial wastewater from agro-food and fermentation industries, (c) treatment of livestock waste, (d) treatment of the organic fraction of municipal solid waste, (e) codigestion of livestock wastes and the organic fraction of

.


municipal solid waste, (f) treatment of energy crops and (g) co-digestion of animal slurries with energy crops. These processes successfully convert biowastes into two economically useful by-products: a renewable energy source (biogas) and a potential fertilizer and soil amendment: the anaerobic digestate (Fig. 1). The former is a gas mixture dominated by methane (Chynoweth and Isaacson 1987; Ahring 2003), and the latter is an organic matrix with agronomic properties (Tietjen 1975; Arthurson 2009; Gell et al. 2011). In recent times, emphasis has been put on the sanitizing aspect of anaerobic digestion with respect to its effect on pathogens or other infectious elements (Luste and Luostarinen 2010; Masse et al. 2011). Thus, producing a safe anaerobic digestate suitable for agricultural land application has become as important as producing the maximum yield of biogas. However, the preponderance of efficiency criteria for methane production can lead to a shorter hydraulic retention time of the material in the digester than the time necessary for full stabilization of the digestate. As a consequence, the end-product digestate may entail issues such as odour emission, toxic organic compounds, pathogens and phytotoxicity.

Unlike manures, composts and sewage sludge which have been extensively studied in the past (Diacono and Montemurro 2010; Hatfield and Stewart 2002; Iakimenko et al. 1996; Williams et al. 1985), research on digestates has yet to reach its full capacity. The bulk of research on anaerobic digestates has been devoted to the evaluation of their stabilities with the objective to reduce their pathogenicity, foul odours and putrescibility (Kirchmann and Bernal 1997; Gomez et al. 2005, 2007; Sanchez et al. 2008; Drennan and Distefano 2010). There has been limited research on the chemical, biochemical and biological properties that would underline digestate agricultural functions (Teglia et al. 2011a). Thus, many question marks pertaining to digestate agronomic functions remain unanswered. This situation is evidenced by cases of conflicting results recently highlighted in a review by Möller and Müller (2012). Moreover, few studies have assessed the impacts of soil applications of digestates on the broader environment (air, soil, water). However, while present knowledge is far from complete, a more comprehensive understanding of the agronomic properties of digestates and their effects on soil and the environment is beginning to emerge. In an attempt to provide answers to lingering questions about anaerobic digestates effectiveness as organic amendments and/or organic fertilizers, this paper successively addresses their amending and fertilizer properties. These properties are then validated through short- and mid-term soil and field crop research findings. Throughout, comparative analysis between anaerobic digestates, animal manure and inorganic fertilizers properties is used to make key inferences. Moreover, this review explores potential environmental impacts of two prominent gases, ammonia and nitrous oxide, emitted by anaerobic digestates upon soil application. In the absence of direct research data, potential environmental issues related to soil contamination by heavy metals, surface and ground waters pollution are inferred from the literature analysis on soil applications of animal slurries. Finally, critical research themes for sustainable soil applications of digestates are highlighted at the end of this review.

\section{Digestates amending properties and effects on soil properties}

\subsection{Amending properties}

There is a wide range of anaerobic digestates whose composition and aspect depend upon the type of biomass inputs (feedstock) used and the configuration of the digester. Thus, spectroscopic techniques have recently demonstrated that
Fig. 1 Basic anaerobic digestion process (a) and its two byproducts: biogas (b) and whole anaerobic digestate (c) (adapted from: Phase 3 Developments \& Investments, LLC (a), 2 degreesnetwork.com (b) and sustainableexperts.com (c))

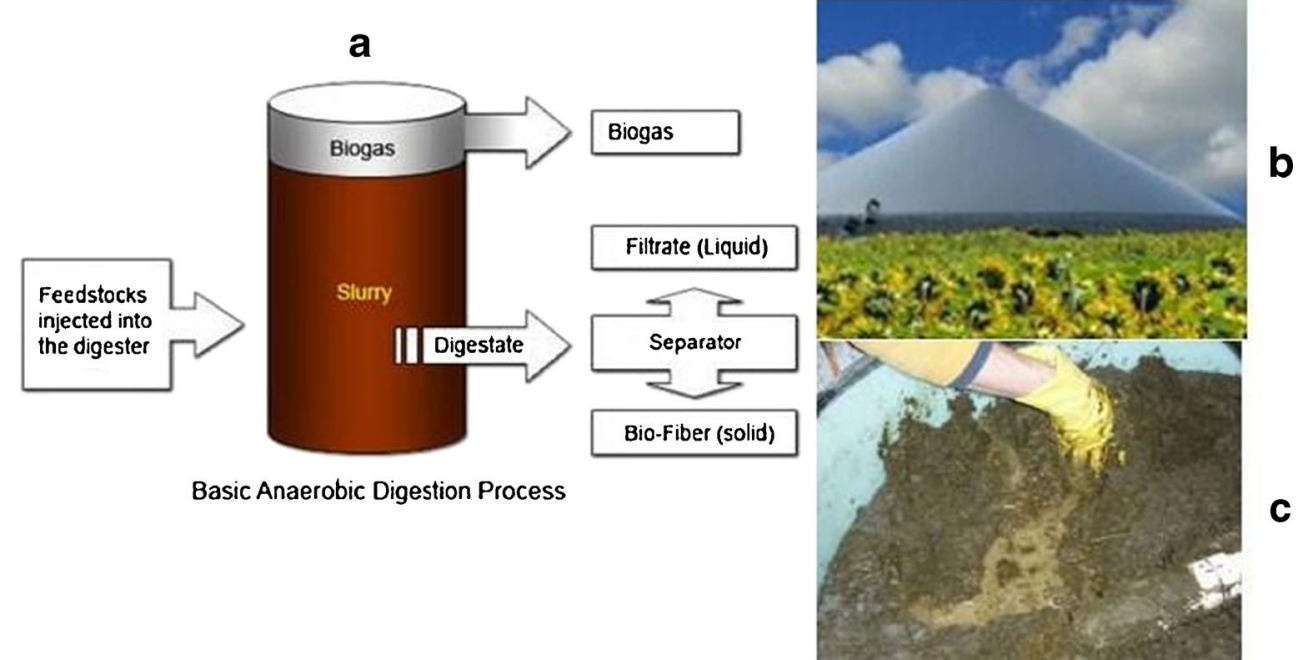


anaerobic digestates inherit the chemical attributes of the feedstock from which they are produced (Provenzano et al. 2011). Various types of feedstock and combinations of feedstocks have been reported, among others, cattle manure (Gomez et al. 2007), livestock manure and agricultural residues (Amon et al. 2007; Tambone et al. 2010), organic solid wastes and sewage sludges (Gomez et al. 2007; Murto et al. 2004), dairy manure and biowastes (Paavola and Rintala 2008), food wastes and landscape wastes (Drennan and Distefano 2010) and potato and sisal pulp wastes (Parawira et al. 2004; Mshandete et al. 2005). The variability in the biochemical properties of anaerobic digestates is considerable, reflecting the diversity of the biomass input (Teglia et al. 2011b; Furukawa and Hasegawa 2006; Voća et al. 2005; Rivard et al. 1995; Möller et al. 2008). Thus, several aforementioned studies show variation intervals of organic matter content (38-75\%), cellulose/lignin ratio (0.22-1.75), oxygen uptake rate $(1,129-3,774)$ and $\mathrm{C} / \mathrm{N}$ ratio $(6.2-24.8)$ (Table 1).

A soil amendment is any material which, upon addition to the soil, would improve or maintain its physical, chemical or biological properties. Organic matter content is the main indicator that defines the status of soil amendment according to the European Committee for Standardization (AFNOR: FD CR 13456 2001). Carbon and nitrogen are the most important constituents of any organic material (Jenkinson et al. 1990; Michalzik et al. 2001; Thornton and McManus 2002). Their relative ratios with respect to their respective mineral and organic forms will influence their agronomic use (Havlin et al. 1990). Some solid digestates show a greater mineral nitrogen fraction $(51-68 \%$ total $\mathrm{N})$ relative to the organic fraction (Paavola and Rintala 2008; Tambone et al. 2009; Tambone et al. 2010) suggesting that their best use would be as fertilizers. In contrast, other type of solid digestates have displayed a lower mineral nitrogen fraction (24-36\% total $\mathrm{N})$ relative to the organic fraction (Teglia et al. 2011b) suggesting that these digestates have a higher potential of valorization as organic amendment. There is little research on the biochemical fractionation of digestate organic matter. This kind of biochemical analysis is used to characterize the structural nature of the organic matter added to soil through amendment. However, variations from 0.22 to 1.75 of the cellulose/lignin or (cellulose + hemicellulose)/lignin ratios of various types of digestates have been reported (Tambone et al. 2009; Teglia et al. 2011b). These ratios have been suggested to be an indicator of the degree of humification of the organic material, since the microorganism-mediated decomposition of cellulose, hemicellulose and lignin leads to the synthesis of humic substances (fulvic acids and humic acids). Humic acids contribute to soil buffer and cation exchange capacities. A value of 0.5 has been suggested to be the threshold that distinguishes between fresh and mature wastes (Komilis and Ham 2003). However, a poor correlation between these biochemical ratios and the state of biodegradation of the organic wastes has been reported (Buffiere et al. 2006; Teglia et al. 2011a), which

Table 1 Biochemical properties of typical anaerobic digestates reported in the literature

\begin{tabular}{|c|c|c|}
\hline Parameters & Value range & References \\
\hline $\mathrm{DM}(\%)$ & $1.5-45.7$ & Svoboda et al. 2013a, b; Teglia et al. 2011a, b; Gutser et al. 2005 \\
\hline OM (\% DM) & $38.6-75.4$ & Teglia et al. 2011a, b; Möller et al. 2008; Voća et al. 2005 \\
\hline Total N (\% DM) & $3.1-14.0$ & Fouda 2011 ; Möller et al. 2008; Voća et al. 2005 \\
\hline Total N (\% FM) & $0.12-1.5$ & Gutser et al. 2005; Kluge et al. 2008; Poetsch et al. 2004 \\
\hline Total $\mathrm{NH}_{4}^{+}(\% \mathrm{FM})$ & $0.15-0.68$ & Svoboda et al. 2013a, b; Ökologischen and Bodenschutz 2008 \\
\hline $\mathrm{NH}_{4}^{+}(\%$ Total $\mathrm{N})$ & $35-81$ & Gutser et al. 2005; Möller et al. 2008; Martin 2004 \\
\hline Total C (\% DM) & $36.0-45.0$ & Möller et al. 2008 \\
\hline $\mathrm{C} / \mathrm{N}$ & $2.0-24.8$ & Gutser et al. 2005; Fouda 2011; Möller et al. 2008 \\
\hline Total P (\% DM) & $0.2-3.5$ & Teglia et al. 2011a, b; Pötsch 2004; Voća et al. 2005 \\
\hline Total P (\% FM) & $0.04-0.26$ & Möller et al. 2010; Ökologischen and Bodenschutz 2008; Kluge et al. 2008 \\
\hline Total K (\% DM) & $1.9-4.3$ & Möller et al. 2010; Pötsch, 2004; Voća et al. 2005 \\
\hline Total K (\% FM) & $0.12-1.15$ & Möller et al. 2010; Ökologischen and Bodenschutz 2008 \\
\hline Total $\mathrm{Mg}(\% \mathrm{FM})$ & $0.03-0.07$ & Kluge et al. 2008; Voća et al. 2005 \\
\hline Total Ca (\% FM) & $0.01-0.023$ & Pötsch 2004; Kluge et al. 2008; Voća et al. 2005 \\
\hline Total S (\% FM) & $0.02-0.04$ & Kluge et al. 2008 \\
\hline CEL/LIGN & $0.22-1.71$ & Tambone et al. 2009; Teglia et al. 2011a, b \\
\hline CEC (meq/100 g) & $20.3-53.4$ & Teglia et al. 2011a, b \\
\hline $\mathrm{OUR}_{\max }\left(\mathrm{mg} \mathrm{O}_{2} / \mathrm{h} / \mathrm{kg} \mathrm{OM}\right)$ & $1,129-6,187$ & Teglia et al. 2011a, b \\
\hline $\mathrm{pH}$ & $7.3-9.0$ & Chantigny et al. 2008; Kluge et al. 2008; Möller et al. 2008; Fouda 2011 \\
\hline
\end{tabular}

$O M$ organic matter, $D M$ dry matter, $C E L / L I G N$ cellulose/lignin, $C E C$ cation exchange capacity, $O U R$ oxygen uptake rate 
would make them unreliable as stability indicators. There is a general agreement in the literature that the content in humic substances (humic and fulvic acids) of organic materials is indicative of their biological maturity, safe and successful impact in soils as organic amendment (Hachida et al. 2009; Campitelli and Ceppi 2008; Teglia et al. 2011a, b). Despite insufficient amount of data relative to the structural fractions of digestate OM, the organic matter levels of typical digestates are in agreement with the European minimal requirement for organic matter ( $20 \%$ of the dry matter of the material), which would describe most, if not all, solid digestates referred to in the literature as soil amendment according to European standards (AFNOR: FD CR 13456 2001).

\subsection{Effects on soil properties}

The long-term impact of anaerobic digestates on soil properties remains an unexplored field of research. A 4-year field trial by Odlare et al. (2008) in eastern Sweden showed that soil chemical properties hardly change in the short term when soil is amended with organic wastes, including digestates. However, relative to other treatments (pig manure, cow manure, compost, inorganic fertilizer), soils treated with liquid digestate from household wastes displayed the highest microbial biomass, nitrogen mineralization rate and potential ammonia oxidation. These results corroborated Tiwari et al.'s (2000). Microbial biomass (Doran and Parkin 1994) and potentially mineralizable nitrogen (Wienhold et al. 2004) are the most commonly suggested biological and chemical indicators for soil quality. An incubation study (Canali et al. 2011) revealed that anaerobic digestates from wine industry mineralized nitrogen at a higher rate than their compost counterparts, which is not always the case as Larsen et al. (2007) reported a significant nitrogen immobilization in the case of anaerobic digestates from bark chips and organic kitchen wastes. However, Canali et al. (2011) observed that nitrogen mineralization of organic products ranked inversely with respect to their $\mathrm{C} / \mathrm{N}$ ratio. Since the feedstock inputs lose their $\mathrm{C}$, as $\mathrm{CO}_{2}$ and $\mathrm{CH}_{4}$, through the anaerobic digestion process, anaerobic digestates generally have a lower $\mathrm{C} / \mathrm{N}$ ratio than their aerobic compost counterparts. Earlier incubation research work (Loria and Sawyer 2005) on digested swine manure described the dynamics of $\mathrm{N}$ and $\mathrm{P}$ in amended soils. Raw and digested swine manure produced similar rates of conversion of $\mathrm{NH}_{4}{ }^{+}$to $\mathrm{NO}_{3}{ }^{-}$, net organic $\mathrm{N}$ and increase in soil test P (STP). At the end of the 112-day incubation period, an average $\mathrm{P}$ recovery of $21 \%$ of the applied $\mathrm{P}$ was estimated, from routine STP methods, in soil amended with digestates. By the same period of time, maximum net extractable inorganic $\mathrm{N}$, predominantly $\mathrm{NO}_{3}{ }^{-}-\mathrm{N}$, averaged $20 \%$ less than total applied $\mathrm{N}$ for both raw and digested manure. The authors concluded that swine digestate was a valuable nutrient resource that producers could use for crop production and should be managed the same way as raw swine manure. Field trials showed similar residual $\mathrm{NO}_{3}{ }^{-}$levels on soils fertilized with swine liquid digestate, raw liquid swine manure and mineral fertilizers (Chantigny et al. 2007). Regarding soil physical properties, field experiments by Garg et al. (2005) showed that the amendment of soils with liquid digestate from agricultural waste reduced bulk density and increased saturated hydraulic conductivity and moisture retention capacity of soils. Möller et al. (2008) showed that after 3 years of amendment, the average soil mineral nitrogen content in a rotation of spelt, winter rye and spring wheat was $36 \%\left(89.2 \mathrm{~kg} \mathrm{~N} \mathrm{ha}^{-1}\right)$ higher in fields that were amended with digested cattle slurry than those amended with farmyard manure.

With the very few exceptions of cases involving feedstock with very high $\mathrm{C} / \mathrm{N}$ ratio, the literature on the short-term effects of digestates on soil properties has consistently noted the improvement of the quality of soils amended with anaerobic digestates. This situation is evidenced by the increase in microbial biomass and N, P contents. Even though data on the impact of digestates on soil physical characteristics are scarce, the work of Garg et al. (2005) highlights the potential of digestates in reducing soil bulk density and increasing its hydraulic conductivity. These findings corroborate the results on the amending properties of typical anaerobic digestates analysed in the previous section, and they strongly indicate that anaerobic digestates can be considered as effective organic amendment materials.

\section{Fertilizer properties and effects on crops}

\subsection{Fertilizer properties of anaerobic digestates}

The nutrient content of anaerobic digestates of all types depends primarily on the nature of the feedstock and the digestion process (Alburquerque et al. 2012; Provenzano et al. 2011). A string of studies conducted by Al Seadi and Moller (2003), Damgaard et al. (2001) and Möller et al. (2010) show that when biogas residues are de-watered, solid fractions of digested cow slurry, pig slurry and mixed manures display significantly higher concentrations in phosphorus, total and organic nitrogen (Table 2), whereas liquid fractions tended to have higher concentrations in available nitrogen. A similar body of work from Tipping (1996) and Zaoui (1988) shows that digested broiler litter liquor has twice as much total nitrogen as the digested dairy slurry liquor, whereas $\mathrm{P}$ and $\mathrm{K}$ concentrations in the latter were 41 and $168 \%$ higher than in the former, respectively (Table 3 ). In light of these results and those regarding the organic matter content (previous section), the outline of two facts emerges: (a) The solid fraction (solid digestate) has a greater potential as soil amendment than the liquid fraction, whereas the latter has a greater potential as fertilizer than the former; (b) the nature of the source material 
Table 2 Dry matter, nitrogen and phosphorus contents in whole, solid and liquid fractions of co-digested wastes and mono-digested cow and pig slurries (adapted from EA 2009)

\begin{tabular}{|c|c|c|c|c|c|c|c|c|c|}
\hline \multirow[t]{2}{*}{ Parameter } & \multicolumn{3}{|c|}{ Digested cow slurry } & \multicolumn{3}{|c|}{ Digested pig slurry } & \multicolumn{3}{|c|}{ Co-digested cow (30\%), pig (50\%), biowaste (20\%) } \\
\hline & Whole & SL & $\mathrm{SF}$ & Whole & SL & $\mathrm{SF}$ & Whole & SL & $\mathrm{SF}$ \\
\hline Dry matter $(\%)$ & 7 & 3.1 & 23 & 5 & 1.5 & 30 & 4 & 1 & 30 \\
\hline Total N (kg/tonne) & 5.47 & 4.6 & 9 & 5.05 & 4.36 & 9.56 & 5.15 & 4.49 & 12.5 \\
\hline Available N (kg/tonne) & 3.29 & 3.3 & 3.3 & 3.78 & 3.79 & 3.72 & 4.12 & 4.13 & 4.0 \\
\hline Organic N (kg/tonne) & 2.18 & 1.3 & 5.7 & 1.27 & 0.57 & 5.84 & 1.03 & 0.36 & 8.5 \\
\hline Phosphate (kg/tonne) & 1.02 & 0.2 & 4.2 & 1.21 & 0.56 & 5.49 & 1.16 & 0.37 & 10.0 \\
\hline
\end{tabular}

$S L$ separated liquor, $S F$ separated fibre

(feedstock) is one of the major determinant of the qualitative value and the potential use of the end-product (digestate). Thus, for example, liquid digestate derived from dairy feedstock would be more suitable for crops that require relatively high amounts of $\mathrm{P}$ and $\mathrm{K}$ such as leguminous plants (Israel 1987; Bethlenfalvay and Yoder 1981; Robson et al. 1981) or crops at the reproductive or blooming phase (Clemens and Morton 1999; Poole and Sheehnan 1980). Conversely, liquid digestate derived from broiler litter would be more suitable for cereal crops, vegetables and grasses, which are crops with high N demand (Nkoa et al. 2001; Marschner 1995). Differing European standards exist with respect to N, P, K requirements for organic fertilizers. Thus, for an organic fertilizer to meet French standards, total $\mathrm{N}, \mathrm{K}_{2} \mathrm{O}$ and $\mathrm{P}_{2} \mathrm{O}_{5}$ must be greater than $3 \%$ in fresh weight, respectively (AFNOR: FD CR 13456 2001). German standards, on the other hand, specify that nutrient contents on a dry matter basis must be greater than $0.5 \%(\mathrm{~N}), 0.3 \%(\mathrm{P})$ and $0.5 \%\left(\mathrm{~K}_{2} \mathrm{O}\right)$ (Siebert 2008). In the current Spanish legislation for fertilisers (PRE/630/2011 2011), anaerobic digestates cannot be considered balanced fertiliser products, and they must be complemented with mineral fertilisers. The British standards (BSI. PAS 110 2010) do not specify any nutrient limit for anaerobic digestates, although a number of parameters such as dry matter, organic matter, $\mathrm{pH}$, salt content, total nitrogen, $\mathrm{P}, \mathrm{K}, \mathrm{Ca}, \mathrm{Mg}, \mathrm{S}, \mathrm{NO}_{3}{ }^{-}$, $\mathrm{NH}_{4}{ }^{+}$, micronutrients, $\mathrm{Cl}$ and $\mathrm{Na}$ should be declared. It is

Table 3 N, P, K and S concentrations in digested municipal solid wastes, dairy cow and broiler litter slurries (adapted from EA 2009)

\begin{tabular}{llll}
\hline Parameter & $\begin{array}{l}\text { Digested dairy } \\
\text { slurry liquor } \\
\left(\mathrm{g} / \mathrm{m}^{3}\right)\end{array}$ & $\begin{array}{l}\text { Digested broiler } \\
\text { litter liquor } \\
\left(\mathrm{g} / \mathrm{m}^{3}\right)\end{array}$ & $\begin{array}{l}\text { Municipal solid } \\
\text { waste digestate } \\
(\% \mathrm{DM})\end{array}$ \\
\hline Total N & 2,500 & 5,544 & 0.84 \\
$\mathrm{P}_{2} \mathrm{O}_{5}$ & 2,800 & 1,980 & 0.3 \\
$\mathrm{~K}_{2} \mathrm{O}$ & 5,300 & 1,980 & 1.3 \\
$\mathrm{~S}$ & 80 & - & 0.2 \\
\hline
\end{tabular}

$D M$ dry matter noteworthy that several anaerobic digestates evaluated in the literature comply with the French standards (Tambone et al. 2010; Teglia et al. 2011a, b; see also Table 2), whereas some do not meet the German standards (E. A. 2009). Regardless of the standards, several authors have concluded lately, following chemical and biological analysis that various anaerobic digestates derived from chicken manure, pig manure, Sudan grass and organic household wastes were valuable fertilizers suitable for agricultural production (Weiland 2010; Birkmose 2009; Amon et al. 2007; Voca et al. 2005).

\subsection{Effects on crop growth and yield}

A few conflicting results pertaining to the effect of anaerobic digestates on crop yields have been recently reported in the literature (Möller and Müller 2012). The effect of anaerobic digestates on crops can be analysed a posteriori with respect to three types of control: unfertilized, undigested feedstock and mineral fertilizers. Thus, digestate research results can be grouped into three categories of performances: (a) performances similar to the unfertilized control (Svensson et al. 2004; El-Shakweer et al. 1998), (b) performances similar or higher than undigested feedstock (Möller et al. 2008; Chantigny et al. 2007; Loria et al. 2007; Mattila et al. 2003; Esteban and Sawyer 2005; Rubaek et al. 1996) and (c) performance equal or better than mineral fertilizers (Ahmad and Jabeen 2009; Chantigny et al. 2008; Tiwari et al. 2000).

\subsubsection{Suboptimal performances of anaerobic digestates and best management practices}

Cases of suboptimal performances when anaerobic digestates were used for barley, oat and wheat production have been reported in the literature (Svensson et al. 2004; El-Shakweer et al. 1998). Interestingly, these research works involved questionable agronomic practices such as field surface application or inappropriate storage and management of digestates. Inappropriate storage and/or application of anaerobic digestates can lead to the loss of their fertilizer value or 
nitrogen use efficiency, through ammonia volatilization, leaching and runoff into surface and ground waters. The mechanisms are well understood: Anaerobic digestion of organic nitrogen results in increased levels of soluble inorganic nitrogen, mainly ammonium (Möller and Stinner 2009) and its equilibrium partner ammonia. The equilibrium relation is dependent on factors such as temperature and $\mathrm{pH}$ : The higher the $\mathrm{pH}$ and temperature, the higher the production of free ammonia (Angelidaki et al. 2003; Hengnirun et al. 1999). Since most liquid digestate $\mathrm{pHs}$ are in the alkaline range, their potential for ammonia loss that is N-nutrient loss is high (see next section). Nutrient nitrogen loss through ammonia volatilization would depend upon variables such as storage conditions (e.g. uncovered slurry tank), methods of land application (Fig. 2) and environmental conditions (heat, wind) during land application (Sommer and Hutchings 2001; Sandars et al. 2003; Holm-Nielsen et al. 2009). For example, manure tanks covered with semi-permeable materials (e.g. straw, Leca granules etc...) can reduce the emission of ammonia by 70 to $80 \%$ (Börjesson and Berglund 2007). The general consensus regarding the methods of application of anaerobic digestates is that injection and incorporation are the methods that minimize the most ammonia volatilization while surface application techniques (splash plate and trail hoses) bring about higher ammonia losses (IEA 2010; Huisjsmans et al. 2002; Wulf et al. 2002a). The drawback of the injection method is its higher cost and greater damage to crops when compared to other methods such as trailing hose, trailing shoe and splash plate. The trailing shoe, a method used on grasslands, appears to be the best alternative when variables such as distribution of slurry, risk of ammonia volatilization, risk of contamination of crop, risk of wind drift and damage to crop are all factored in.

\subsubsection{Fertilizer value of anaerobic digestates}

The fertilizer value of anaerobic digestates can be assessed directly from the relative proportion of the amount of mineral fertilizer necessary to obtain the same yield of crop, or through field performance comparisons with universally recognized organic (Lafleur et al. 2012; Gong et al. 2011; Hasegawa et al. 2005; Adeli et al. 2005; Burns et al. 1987) or inorganic commercial fertilizers. A few authors have calculated the fertilizer value of anaerobic digestates. Gutser et al. (2005) compared the characteristics of 15 sources of organic fertilizers (Table 4). They found that anaerobically co- and monodigested feedstocks had the fifth and sixth highest fertilizer values (50-70 and 40-60\%, respectively), just behind sources such as urine, poultry slurry, dried poultry excrements and meat/blood/bone meal and interestingly ahead of traditional sources such as cattle slurry, solid manure, sewage sludge, green manure and biocompost. Similar results were reported by Herrmann et al. (2013): Anaerobic digestates obtained from the co-digestion of animal slurries and maize ensilage displayed a relative nitrogen fertilizer value $30 \%$ higher than those of cattle and pig slurries. With respect to field performances, many authors have shown that anaerobic digestates have similar or greater crop performance than corresponding undigested animal manures and slurries (Bachmann et al. 2011; Möller et al. 2008; Chantigny et al. 2007; Loria et al. 2007; Mattila et al. 2003; Esteban and Sawyer 2005; Rubaek
Fig. 2 Four typical methods of digestate application: splash-plate surface application (a), injection (b), trailing hose (c) and trailing shoe (d) (adapted from: Claudia Wagner-Riddle's University of Guelph team (a), extension.org (b), commons.wikimedia.org (c) and abbeymachinery.com (d))
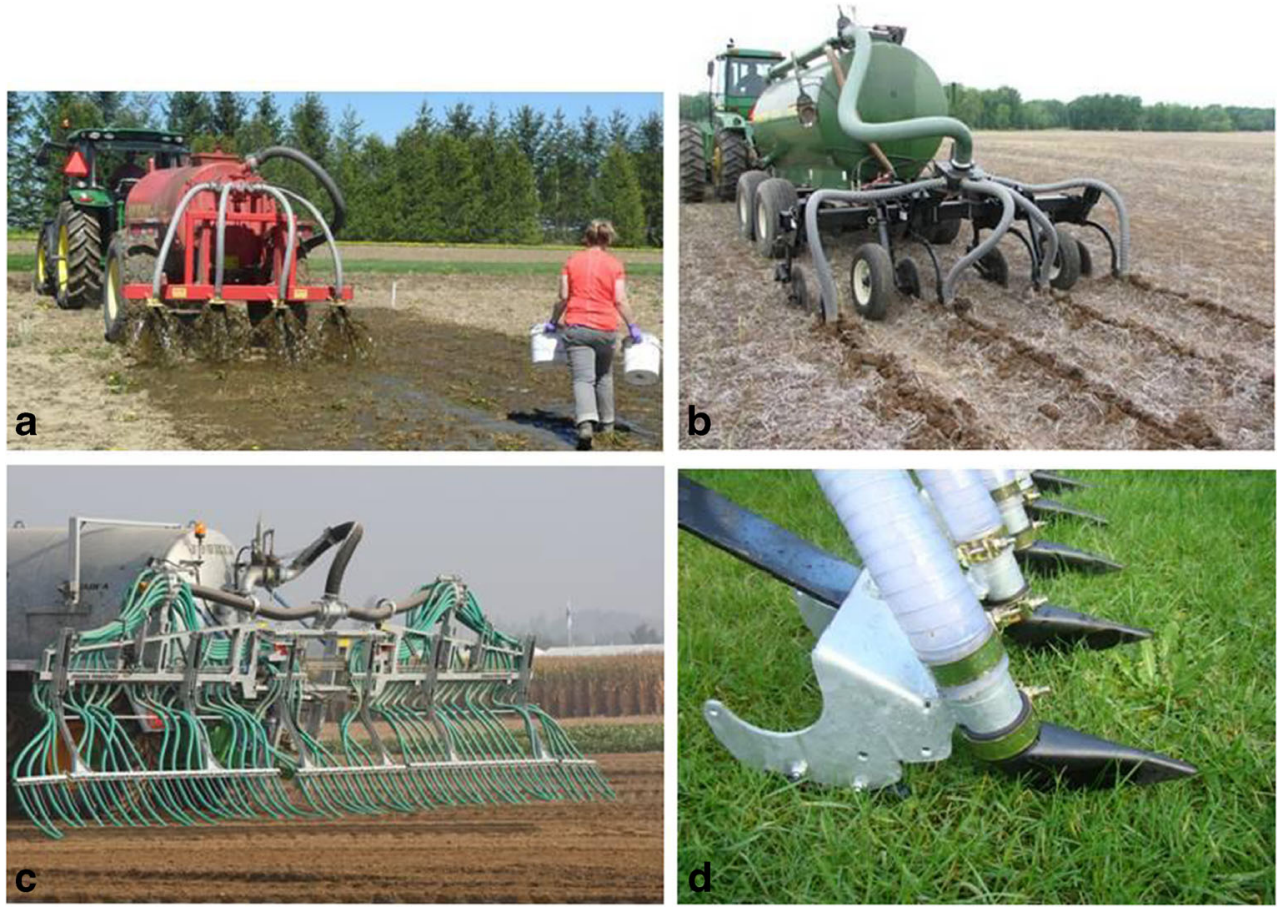
Table 4 Fertilizer properties of typical organic materials (Gutser et al. 2005)

\begin{tabular}{lllllll}
\hline Organic material & $\mathrm{N}$ content & Dry matter $(\%)$ & $\mathrm{NH}_{4}^{+}(\%$ total N) & $\mathrm{C} / \mathrm{N}$ & Biodegradability & Fertilizer value (\%) \\
\hline Legume coarse meal & $40-60 \mathrm{~kg} \mathrm{t}^{-1}$ & 95 & $0-5$ & $10-13$ & High & $35-45$ \\
Horn/feather/leather meal & $130 \mathrm{~kg} \mathrm{t}^{-1}$ & 95 & $0-5$ & $3-4$ & High & $50-70$ \\
Brewery/distillery residues & $3 \mathrm{~kg} \mathrm{~m}^{-3}$ & 6 & $0-5$ & $8-10$ & High & $30-35$ \\
Meat/blood/bone meal & $75-120 \mathrm{~kg} \mathrm{t}^{-1}$ & 95 & $5-10$ & $3-5$ & Very high & $60-80$ \\
Green manure & $10-35 \mathrm{~kg} \mathrm{t}^{-1}$ & 100 & $0-10\left(\mathrm{NO}_{3}^{-}-\mathrm{N}\right)$ & $10-30$ & Low medium & $10-40$ \\
Biocompost & $6 \mathrm{~kg} \mathrm{~m}^{-3}$ & 60 & $0-15$ & $13-20$ & Low & $0-20$ \\
Solid manure & $6 \mathrm{~kg} \mathrm{~m}^{-3}$ & 25 & $5-20$ & $12-15$ & Low & $10-20$ \\
Sewage sludge (high DM) & $4-5 \mathrm{~kg} \mathrm{t}^{-1}$ & 25 & $5-20$ & $6-8$ & Medium & $15-30$ \\
Dried poultry excrements & $30 \mathrm{~kg} \mathrm{t}^{-1}$ & 55 & $5-30$ (uric acid) & 5 & High & $60-70$ \\
Sewage sludge (low DM) & $1-2 \mathrm{~kg} \mathrm{~m}^{-3}$ & 5 & $30-40$ & $3-5$ & Medium & $45-55$ \\
Cattle slurry & $4 \mathrm{~kg} \mathrm{~m}^{-3}$ & 7.5 & $40-60$ & 8 & Low & $35-45$ \\
Digestate from plant biomass & $2-3 \mathrm{~kg} \mathrm{~m}^{-3}$ & 8 & $35-60$ & $2-5$ & Low & $40-60$ \\
Digestate with co-fermentation & $3-15 \mathrm{~kg} \mathrm{~m}^{-3}$ & 5 & $45-70$ & 4 & Medium & $50-70$ \\
Poultry slurry & $10 \mathrm{~kg} \mathrm{~m}^{-3}$ & 15 & $60-80$ & $8-2$ & - & $70-85$ \\
Urine & $4 \mathrm{~kg} \mathrm{~m}^{-3}$ & 2 & & & $90-100$
\end{tabular}

$D M$ dry matter

et al. 1996), which factually demonstrates their high fertilizer value.

Relative to mineral commercial fertilizers, numerous studies across the world have shown that anaerobic digestates were at least as effective as mineral fertilizers. Thus for instance, in vegetable production, a digestate derived from household wastes was shown to be a quick-release nitrogen fertilizer comparable to inorganic synthetic fertilizer and did not cause contamination by coliform groups, Escherichia coli, faecal streptococci and vibrio parahaemolyticus in the soil and on spinach (Spinacia oleracea L.) and Komatsuna (Brassica rapa var. perviridis L. H.) leaves (Furukawa and Hasegawa 2006). Similarly, liquid digestates from swine slurries were found as good nutrient sources as chemical fertilizers to water spinach (Ipomea aquatica Forssk.) (Lam et al. 2002), cucumber (Cucumis sativus L.) and tomato (Lycopersicon esculentum Mill.) grown in pig-biogas-vegetable greenhouse systems (Qi et al. 2005).

Regarding cereal and cash crops production, a recent work by Haraldsen et al. (2011) on barley fertilization has established that a liquid anaerobic digestate, from sourceseparated household wastes, had the same performance as the mineral NPK fertiliser Fullgjødsel ${ }^{\circledR}$, which led the authors to recommend the digestate for cereal production. It has been reported that substantial amounts of synthetic mineral nitrogen could be replaced by biogas slurries in wheat cropping Tiwari et al. (2000). Likewise, liquid digestates derived from cattle manure had similar results to chemical fertilizers, when they were spread into fields of timothy (Phleum pratense L.) and legumes, wheat (Triticum aestivum L.), sugar beet (Beta vulgaris L.) and potato (Solanum tuberosum L.) (Civil Engineering Research Institute of Hokkaido 2003).
In India, a liquid digestate from cow manure had been incorporated into the organic farming system where it is associated with an on-farm product Panchavgaya (a concoction of five cow products: dung, urine, milk, curd and ghee). Somasundaram et al. (2007) reported that this combination outperformed synthetic mineral fertilizer in corn and sunflower (Helianthus annus L.) production. These results were confirmed by Ahmad and Jabeen (2009) when they reported an improvement of the growth and development, as expressed by height, leaf area index and yield, of sunflower plants fertilized with a liquid digestate from cow dung. Chantigny et al. (2008), after studying the yield and nutrient export of maize fertilized with liquid digestate from swine manure, concluded that when side-dressed to corn and immediately incorporated, liquid digestates from swine manure had the same fertilizer value as mineral fertilizer. Regarding nutrient uptake, Chantigny et al. (2007) showed that nitrogen uptake by forage crop grown on soils amended with swine liquid digestates was similar to that observed with inorganic synthetic fertilizers, but was lower with raw, decanted and filtered liquid swine manures.

The pattern of the effect of digestates on crop growth and yield observed from various studies across the world is consistent and clear. Not only chemical compositions of anaerobic digestates fit most European legal definitions of an organic fertilizer, their field-validated fertilizer values lie between those of two universally accepted fertilizers: raw manure and commercial inorganic fertilizer. Therefore, anaerobic digestates can be regarded as effective organic fertilizers when appropriate storage and application methods are employed. However, in many instances, good field performances of digestates appear to contradict national standards that define 
organic fertilizers such as German's. This type of contradiction can be resolved by redefining the concept of organic fertilizer so that it is based on their fertilizer value.

\section{Environmental risks associated with land applications of anaerobic digestates}

Biogas and anaerobic digestates are the two by-products of anaerobic digestion. Each poses a threat to one or several components of the broader environment. Leakage of methane and carbon dioxide, two greenhouse gases (GHG), from the digester can contribute to global warming, whereas anaerobic digestates can directly impact soils, water bodies and the atmosphere. Since the initial feedstocks have been depleted of most of their easily degradable carbon during digestion, nitrous oxide is the only significant GHG that can be potentially be released by anaerobic digestates. Inappropriate storage or application of anaerobic digestates can lead to gaseous nitrogen emission (ammonia and nitrous oxide) and/or nutrients leaching and runoff into surface and ground waters (Fig. 3).

\subsection{Risks of atmospheric pollution}

During the anaerobic digestion process, a large fraction of carbonaceous compounds are converted to methane and carbon dioxide, which are collected as biogas. As a result, the proportion of carbon decreases in the biogas residues while that of nitrogen increases in the form of $\mathrm{NH}_{4}-\mathrm{N}$, hence a lower $\mathrm{C} / \mathrm{N}$ ratio (Gutser et al. 2005; Svensson et al. 2004). Concomitantly, fatty acids are degraded and calcium ions released from the degradation of organic matter leading to digestate $\mathrm{pH}$ increase (Weiland 2010). High $\mathrm{pH}$ and $\mathrm{NH}_{4}$ concentration are conditions that favour $\mathrm{NH}_{3}$ emission.

\subsubsection{Ammonia emission and fallout}

Ammonium and its equilibrium partner ammonia are found at higher concentrations in liquid digestates (Alburquerque et al. 2012; Kaparaju et al. 2012; Möller and Stinner 2009). Factors such as temperature and $\mathrm{pH}$ can alter this equilibrium and hence determine which form is released into the environment, or which component of the environment (air, soil and water) is affected.

Agricultural and environmental significance of ammonia emission Ammonia $\left(\mathrm{NH}_{3}\right)$ volatilization has been estimated to account for $15 \%$ of the total applied nitrogen (Sommer and Hutchings 2001; Matsunaka et al. 2006; Möller and Stinner 2009; Terhoeven-Urselmans et al. 2009). $\mathrm{NH}_{3}$ emission inventories from several countries have shown that agriculture produces approximately $90 \%$ of the total emission of $\mathrm{NH}_{3}$ to the atmosphere (Misselbrook et al. 2000; Buijsman et al. 1987). It is estimated that emissions from agriculture range from 186,000 to $405,000 \mathrm{Mg} \mathrm{NH}_{3}-\mathrm{N}_{\text {year }}{ }^{-1}$ in $\mathrm{UK}$ alone (Buijsman et al. 1987; Ryden et al. 1987; Kruse et al. 1989; Jarvis and Pain 1990; Asman 1992). Asman and Van

Fig. 3 Sequence of events leading to the pollution of a surface water body following an inappropriate application of anaerobic digestate. 1 Winter surface application of anaerobic digestates, 2 runoff during spring thaw and 3 discharge of nutrients in a water body (adapted from: CPEPESC (1); OMAFRA (2 and 3))

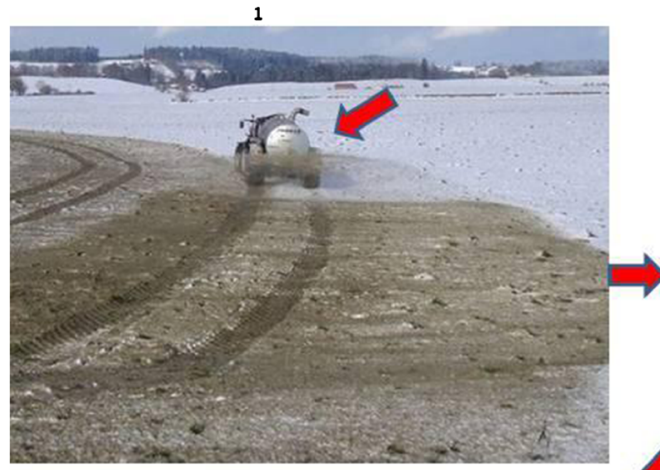
3

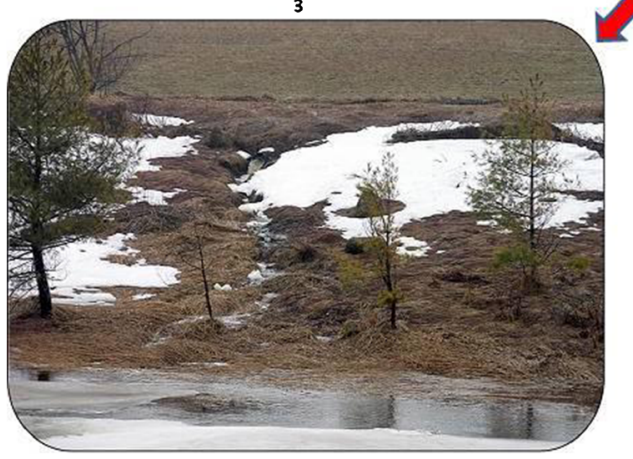


Jaarsveld (1990) estimated that 80 to $90 \%$ of total ammonia emitted from livestock operations is redeposited within $10 \mathrm{~km}$ of the source, while about $20 \%$ is returned to earth within $1 \mathrm{~km}$. The remainder is dispersed into the atmosphere, sometimes over hundreds of kilometres. Acid rains that result from atmospheric deposition of ammonia contribute to the acidification of terrestrial and aquatic ecosystems as well as the eutrophication of surface water bodies (Fangmeier et al. 1994; Erisman and Monteny 1998; Dragosits et al. 2002; Krupa 2003; Sanderson et al. 2006).

Ammonia emissions are a major air quality concern at national, regional and global levels (NRC 2002). Ammonia gas, once emitted, reacts and neutralizes atmospheric gaseous $\mathrm{H}_{2} \mathrm{SO}_{4}, \mathrm{HNO}_{3}$ and $\mathrm{HCl}$ to form soluble ammonium aerosol salts $\mathrm{NH}_{4} \mathrm{SO}_{4}, \mathrm{NH}_{4} \mathrm{NO}_{3}$ and $\mathrm{NH}_{4} \mathrm{Cl}$ in the sub-micron size range (McMurry et al. 1983; Warneck 2000), which, depending on the relative humidity in the atmosphere (Tang and Munkelwitz 1977; Tang 1980), may be deposited back onto earth. Beside surface water eutrophication and ecosystem acidification mentioned above, the negative environmental impact of ammonia deposition also includes phytotoxicity (Van der Eerben et al. 1998; Pitcairn et al. 1998) and the reduction of plant biodiversity (Goulding et al. 1998). Soils surrounding ammonia emission sources can sorb $\mathrm{NH}_{3}(\mathrm{HaO}$ et al. 2005, 2006), which could complicate fertilizer and manure application recommendations for crop production.

In addition to its effects on soil systems and plants, ammonia-derived particulate matter with a diameter of 2.5 microns or less, known as PM2.5, can penetrate deep into the lungs and cause serious health issues such as respiratory and cardiovascular problems. They also contribute to the formation of haze. Thus, for example, in the USA, haze has reduced natural visibility from 90 miles to between 15 and 25 miles in the east and from 140 miles to between 35 and 90 miles in the west (EPA 2004).

Ammonia emission from anaerobic digestates Ammonia emission from anaerobic digestates is affected by management and environmental factors such as storage conditions, methods of application, concentrations of ammonia in the digestate, $\mathrm{pH}$, temperature, air velocity, surface area and moisture (Sommer and Hutchings 2001; Sandars et al. 2003; Holm-Nielsen et al. 2009). Given the higher $\mathrm{NH}_{3} / \mathrm{NH}_{4}$ concentration and $\mathrm{pH}$ in anaerobic digestates relative to livestock manures (Haraldsen et al. 2011; Möller et al. 2008; Chantigny et al. 2008) and the intensification of biogas production across the world, biogas plants and associated crop fields are expected to be major sources of emission of ammonia. For illustration, field experiments (Misselbrook et al. 2000) show that $\mathrm{NH}_{3}$ emission from land application of cattle and pig slurries range from 15 to $60 \%$ of the total ammoniacal nitrogen applied, which values for dairy cows and all other cattle were estimated between 2.25 and $1.75 \mathrm{~kg} \mathrm{~m}^{-3}$ slurry, respectively
(MAFF 1995). $\mathrm{NH}_{3}$ emissions from poultry manure spread onto land were estimated at $45 \%$ of ammoniacal and uric acid nitrogen applied (Nicholson et al. 1996; Chambers et al. 1997). In theory, these emissions factors are expected to be higher in lands spread with biogas digestates because of their higher $\mathrm{pH}$ and $\mathrm{NH}_{3}$ contents. In fact, several studies have found similar (Chantigny et al. 2004; Pain et al. 1990) or higher emissions than raw manures (Ni et al. 2012; Gericke 2009; Amon et al. 2006; Wulf et al. 2002a). In contrast, Rubaek et al. (1996) reported lower emissions with digested than with raw manure. Specifically, $\mathrm{NH}_{3}$ emissions after anaerobic digestates application were estimated between 7 and $24 \%$ of applied $\mathrm{NH}_{4}-\mathrm{N}$ as opposed to 3 to $8 \%$ for animal slurries (Gericke 2009). Wulf et al. (2002a) have precisely quantified these emissions at about 350, 275, 160 and $50 \mathrm{mg}$ $\mathrm{NH}_{3}-\mathrm{N} \mathrm{m}^{-2} \mathrm{~h}^{-1}$ within the first $10 \mathrm{~h}$ following application of liquid digestate through splash plate, trailing shoe, harrow and injection methods, respectively. Ten years later, $\mathrm{Ni}$ et al. (2012) quantified and compared the $\mathrm{NH}_{3}$ emission rates of anaerobic digestates, cattle and pig slurries applied through the trailing hose method at 120 and $80 \mathrm{~kg} \mathrm{NH}_{4}{ }^{+}-\mathrm{N} \mathrm{ha}^{-1}$. They found that $20 \mathrm{~h}$ after the application, digestates out-emitted cattle and pig slurries (Fig. 4).

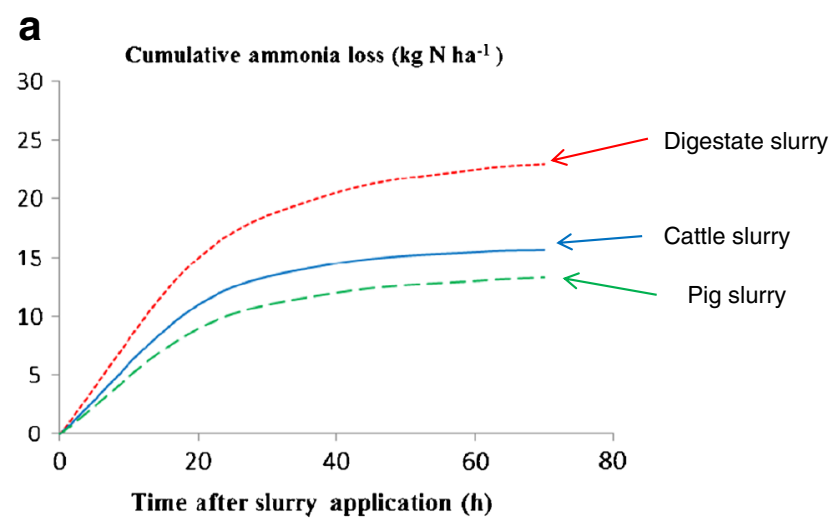

b

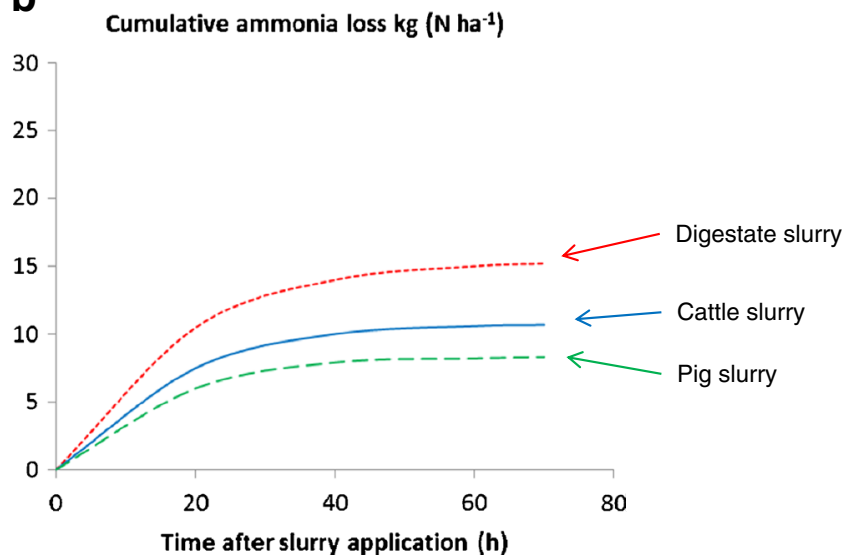

Fig. 4 Cumulative ammonia loss by digestate, cattle and pig slurries spread onto land under identical conditions. a $120 \mathrm{~kg} \mathrm{NH}_{4}-\mathrm{N} \mathrm{ha}^{-1}$; b $80 \mathrm{~kg} \mathrm{NH}_{4}-$ $\mathrm{N} \mathrm{ha}^{-1}$ (adapted from Ni et al. 2012) 


\subsubsection{Nitrous oxide emission}

Besides ammonia, nitrous oxide $\left(\mathrm{N}_{2} \mathrm{O}\right)$ may also be significantly emitted following field applications of anaerobic digestates (Vallejo et al. 2006; Wulf et al. 2002b).

Environmental and agricultural significance of $\mathrm{N}_{2} \mathrm{O}$ emission Nitrous oxide is one of the most important greenhouse gases and ozone-depleting chemical compounds released on earth (Ravishankara et al. 2009; Metz et al. 2007). Its global warming potential is 310 times higher than that of carbon dioxide (Börjesson and Berglund 2007). Soils in general contribute more than half of the world's emission, and agricultural soils in particular account for about half of total soils emissions (Denman et al. 2007). Here, the main contributing factors are high nitrogen inputs, intensive cropping systems, edaphic and climatic variables (Mosier et al. 1998a, b). Specifically, episodic $\mathrm{N}_{2} \mathrm{O}$ emission bursts related to the process of freezing and thawing of agricultural soils can account for up to $73 \%$ of the annual soil $\mathrm{N}_{2} \mathrm{O}$ emission budget (Lemke et al. 1998; Wagner-Riddle et al. 1997).

Spring-thaw emission bursts are attributable to the physical release of $\mathrm{N}_{2} \mathrm{O}$ entrapped under frozen surface layers during winter and the new production of $\mathrm{N}_{2} \mathrm{O}$ at the onset of thaw (Risk et al. 2013). In soils, nitrous oxide can be produced through three biochemical and one chemical pathways depending upon the availability of oxygen or the soil $\mathrm{pH}$. The biochemical pathways are those of the nitrification and denitrification processes. In oxygen-saturated soils, $\mathrm{N}_{2} \mathrm{O}$ can be produced though the oxidation of hydroxylamine $\left(\mathrm{NH}_{2} \mathrm{OH}\right)$, an intermediate step of nitrification (Sutka et al. 2003). In hypoxic soils, nitrifying bacteria (Nitrosomas, Nitrosococcus, Nitrobacter, Nitrococcus) may reduce nitrite $\left(\mathrm{NO}_{2}{ }^{-}\right)$to $\mathrm{N}_{2} \mathrm{O}$ (Wrage et al. 2001). In anoxic soils, $\mathrm{N}_{2} \mathrm{O}$ can be released during denitrification when denitrifiers (Paracoccus, Pseudomonas, Thiobacillus) reduce nitrate $\left(\mathrm{NO}_{3}{ }^{-}\right)$to dinitrogen $\left(\mathrm{N}_{2}\right)$. Finally, in acidic soils, $\mathrm{N}_{2} \mathrm{O}$ can be formed by chemodenitrification (Goodroad and Keeney 1984).

Nitrous oxide emission from anaerobic digestates In general, $\mathrm{NH}_{3}$ emissions tend to be higher with digested than undigested slurries. On the contrary, $\mathrm{N}_{2} \mathrm{O}$ emissions from digested materials are generally lower than emissions from undigested feedstock. It has been hypothesized that this is the result of lower contents in easily degradable $\mathrm{C}$ in digested feedstock, hence less energy source for denitrifiers (Vallejo et al. 2006; Rochette et al. 2000). Thus, several comparative studies have shown lower $\mathrm{N}_{2} \mathrm{O}$ emissions on land spread with digested slurries (Collins et al. 2011; Chantigny et al. 2007; Amon et al. 2006; Vallejo et al. 2006; Petersen 1999). Specifically, Börjesson and Berglund (2007) reported an average reduction of $\mathrm{N}_{2} \mathrm{O}$ emissions from 40 (undigested) to $25 \mathrm{~g}$ (digested) $\mathrm{N}_{2} \mathrm{O}$ per tonne of manure applied. Beside the aforementioned soil characteristics that influence $\mathrm{N}_{2} \mathrm{O}$ emission, soil texture is a determinant as well. Thus, Chantigny et al. (2007) reported a 54-69 \% lower $\mathrm{N}_{2} \mathrm{O}$ emission with the digested than with undigested manure in a loam soil, as opposed to a $17-71 \%$ lower emission in a sandy loam. As far as best management practices are concerned, it is generally accepted that spring applications of manures and slurries mitigate runoff and leaching of nutrients. It appears that spring (post-thaw), unlike fall (pre-thaw), applications would mitigate nitrous oxide emissions via the reduction of the amount of substrates necessary for the accomplishment of $\mathrm{N}_{2} \mathrm{O}$-related freeze-thaw processes. Beside the time of application, agricultural practices that enhance soil aeration and good drainage would also mitigate $\mathrm{N}_{2} \mathrm{O}$ emissions following the application of anaerobic digestates.

\subsection{Risks of nutrient pollution}

A major environmental concern with land application of biogas digestates is the potential contamination of surface and ground waters with excess nitrogen and phosphorus. Most studies show that digestates are richer, in terms of nutrient contents, than their respective raw manure counterparts (Haraldsen et al. 2011; Möller et al. 2008; Chantigny et al. 2008; Gomez et al. 2007; Loria and Sawyer 2005). Consequently, environmental issues associated with the production and land applications of manures are equally, perhaps potentially more prominent with anaerobic digestates, in particular, issues such as surface and groundwater pollution and eutrophication of water bodies, which have been documented and linked to the production and use of manure (Mulla et al. 2001; Hubbard and Lowrance 1998; Newton et al. 1994; Odgers 1991).

Nitrogen leaching has received most of the attention from researchers due to the considerable amount of nitrogen in animal manures and slurries. These high $\mathrm{N}$ levels are attributable to the low animal N-use efficiency (Oenema and Tamminga 2005). To illustrate, only 20 to $30 \%$ of the nitrogen taken up by dairy cows are converted into meat and milk; the balance is excreted as faeces and urine. The organic $\mathrm{N}$ fraction in the excrements is further digested in the bioreactor where the retention times are much longer than in animal digestive tracts. This may explain the higher $\mathrm{NH}_{4}-\mathrm{N}$ generally observed in digested as compared to undigested slurries. When anaerobic digestates are applied into soils, $\mathrm{NH}_{4}{ }^{+}$are either absorbed by plant root cells, or adsorbed on negatively charged soil particles, or oxidized to $\mathrm{NO}_{3}{ }^{-}$by nitrifying microorganisms. For example, a 4-year field study in Sweden showed that the application of anaerobic digestates increased the rate of potential ammonia oxidation (Odlare et al. 2008), and the analysis on $\mathrm{N}$ fractions in leachates obtained from fields treated with anaerobic digestates revealed that nitrate- $\mathrm{N}$ was the 
dominant fraction, and ammonium $\mathrm{N}(0.3 \%)$ and organic $\mathrm{N}$ (6\% of total $\mathrm{N}$ ) only contributed marginally (Svoboda et al. 2013a; Wachendorf et al. 2006). Due to their negative charges, nitrate are hardly adsorbed onto soil particles, hence their high mobility through the soil and their high polluting potential. Reported results of studies that compared $\mathrm{N}$ leaching after applications of digested and undigested slurries vary widely, most likely because of the variability of soil types and factors that govern ammonia and nitrous oxide emissions. Thus, (a) no significant differences in $\mathrm{N}$ concentrations were detected in leachates under fields treated with animal slurries and anaerobic digestates (Svoboda et al. 2013a, b; Pötsch 2004); (b) a $5 \%$ higher nitrate $\mathrm{N}$ loss was observed in crop rotation treated with digested as opposed to raw slurries (Jørgensen and Petersen 2006); (c) a lower $\mathrm{N}$ leaching was reported after application of anaerobic digestates compared to undigested slurry (Jäkel and Mau 1999) and (d) inconsistent results of nitrate $\mathrm{N}$ leaching have been observed across years between raw and digested cattle slurries (Brenner and Clemens 2005). From the literature analysis, it can be concluded that anaerobic digestates pose at least a similar threat than animal manures and slurries to water bodies as far nutrient leaching is concerned.

Nutrient leaching potential following application of anaerobic digestates depends upon factors such as fertilisation strategies (e.g. time and methods of application), soil texture (e.g. sandy and clayey soils), topography (risk of runoff; see Fig. 3), precipitations and cropping systems. Best management practices that can be utilized to mitigate nutrient leaching include adjustment of digestate nutrient supply to crop demand and soil tests, synchronization of nutrient release with crop developmental demand, cultivation against slopes, avoidance of fall applications, long time gaps between digestate application and sowing, and applications that precede heavy rains.

\subsection{Risk of soil contamination}

Land application of anaerobic digestates may introduce into soils physical, chemical and biological contaminants which may jeopardize their long-term agricultural productivity. Physical contaminants include plastics, glasses, stones etc... The focus of this review is on chemical and biological contaminations.

\subsubsection{Chemical contamination}

Land application of organic wastes is not risk-free, since it may result in the incorporation into the soil of phytotoxic compounds (Boydston et al. 2008; Gough and Carlstrom 1999; Liu and Christians 1994), pathogens (Watcharasukarn et al. 2009; Grewal et al. 2006; Reddacliff et al. 2003; Gantzer et al. 2001) and heavy metals (Alburquerque et al. 2012;
Wong et al. 1996; Jacobs 1981). With respect to phytotoxicity of digestates, causal compounds include ammonia (Leege and Thompson 1997; Wong et al. 1983), volatile organic acids (Drennan and DiStefano 2010; Abdullahi et al. 2008; PoggiVaraldo et al. 1999; DeVleeschauwer et al. 1981), phenolic compounds (Inglet et al. 2009; Gorsuch et al. 1990) and salts (McLachlan et al. 2004). Regarding heavy metals (Ni, Pb, Cr, Cd), several studies (Alburquerque et al. 2012; Schievano et al. 2009; Siebert et al. 2008; Edelmann et al. 2004) have reported lower levels in digestates relative to the standards set by Spanish, British and German legislations (BSI. PAS 110 2010; Siebert et al. 2008). However, agriculturalists and environmentalists should bear in mind that those concentrations of heavy metals within the limits of standards do not preclude the possibility of land contamination in the long run owing to the long-term accumulation over repeated applications. Also of serious concern are the high concentrations in some digestates of some micronutrients such as $\mathrm{Cu}$ and $\mathrm{Zn}$ (Alburquerque et al. 2012) due to the use of pig and cattle slurry as feedstock. These two elements are used as additives to stimulate livestock growth and prevent pig and cattle diseases. Beside heavy metals, micronutrients as a whole could be a threat to sustainable agriculture. A recent survey across Europe has disclosed the abundance of micronutrients in all digesters, especially those supplied with wastes like blood, kitchen and food wastes (Schattauer et al. 2011). For illustration, $\mathrm{Cu}$ and $\mathrm{Zn}$ can potentially jeopardize the sustainability of agricultural soils through soil accumulation and interference with the metabolic activities of plants. Thus, although they both play essential metabolic roles as metallic enzyme activators, or cofactor of RNA and DNA polymerase ( $\mathrm{Zn})$, in cell growth stimulation (Burgess et al. 1999), they can inhibit plant growth once in excess in the soil solution (Ebbs and Kochian 1997; Pahlsson 1989). Both metals synergistically inhibit the absorption by plants of $\mathrm{Fe}$ and $\mathrm{Mn}$.

Speaking of manganese, it is an essential element for plant growth and development. It can, however, be detrimental when available in excess. Concentrations as low as $1 \mathrm{ppm}$ can be toxic to most field, horticultural, flower and forage crops (Morris and Pierre 1947; Berger and Gerloff 1947; Jacobson and Swanback 1932). Excess Mn in the soil solution can interfere with the absorption, translocation and the metabolism of other mineral elements such as $\mathrm{Ca}, \mathrm{Mg}, \mathrm{Fe}$ and $\mathrm{P}$ (Clark 1982). Inside plant tissues, excess Mn can inhibit the activities of enzymes and hormones involved in essential Mnrequiring metabolic activities (Horst 1988; Epstein 1961). The overall result of manganese toxicity is a significant reduction of plant growth and development, as well as yield. Mn toxicity in agriculture is often more important than Mn deficiency in many parts of the world. Common determinants of Mn toxicity are poor drainage, soil acidity ( $\mathrm{pH}$ below 5.5) (Chesworth 1991; Morris and Pierre 1947); soil with high pHs under reducing conditions that result from flooding, compaction or 
organic matter accumulation (Kamprath and Foy 1971) and high temperature or high light intensity (El-Jaoual and Cox 1998). The concentration of Mn in digestates can be as high as 50-55 ppm (Bischofsberger et al. 2005; Sahm 1981). Repeated long-term applications of digestates onto lands may result in $\mathrm{Mn}$ and organic matter accumulation, factors that favour Mn toxicity, especially in soils with low Mn sorption capacity.

\subsubsection{Biological contamination}

Numerous pathogenic bacteria species have been tallied in organic wastes used for anaerobic digestion (Sahlstrom 2003). The risk is higher when manure is included as feedstock, since several outbreaks of gastroenteritis have been linked to livestock operations (Spencer and Guan 2004; Pell 1997). Bacteria such as Salmonella, E. coli, Yersinia, Campylobacter and the protozoa Giardia and Cryptosporidium are the most prevalent pathogenic microorganisms found in manures (Bicudo and Goyal 2003; Hutchison et al. 2005). Other bacteria such as Clostridium perfringens, Listeria monocytogenes and Treponema hydrosenteriae have also been reported as causal agents of human infections related to livestock (Colleran 2000).

Mitigation of the risk of pathogens embedded in the feedstock occurs through integrated or post-sanitation configuration of the anaerobic digestion process (Angelidaki et al. 2003; Olsen et al. 1985; Olsen and Larsen 1987; Masse et al. 2011). Despite the hygienization process, the persistence of pathogenic parasite eggs, bacteria and fungi has been reported in many biogas plants (Plymforshell 1995; Sahlstrom 2003; Schnurer and Schnurer 2006; Slana et al. 2011). Recent studies (Bonetta et al. 2011; Goberna et al. 2011) showed that the hygienic quality of digestate products improved dramatically, relative to the initial cattle manure input, for almost all microbiological parameters but $L$. monocytogenes. In light of the aforementioned results, it appears that there should be a protocol that identifies specific pathogen indicators in order to characterize digestate products.

The microbiological status of the output digestate depends on the quality of the input feedstock and on the configuration features of the digester such as pre-treatment (pasteurisation), digestion temperature, $\mathrm{pH}$, ammonia concentration, hydraulic retention time, among others (Sahlstrom 2003; Ottoson et al. 2008). The persistence of some pathogens in digestates can be explained by the presence of bacteria species capable of forming spores in animal wastes (Snell-Castro et al. 2005). These spore-formers are not eliminated during the anaerobic digestion process (Olsen and Larsen 1987; Sahlstrom et al. 2004; Bagge et al. 2005; Goberna et al. 2009). Regrowth of pathogens and their spores can also occur in storage facilities (Sidhu et al. 2001; Pepper et al. 2006). Stabilization of digestates through post-treatment measures such as curing (Drennan and DiStefano 2010) and composting (Tiquia et al. 1996; Smet et al. 1998) significantly reduces the risk they pose on human health and the broad environment.

\section{Research needs}

5.1 Relationships between the type of feedstock and the agronomic properties of digestates

For a model of anaerobic digestion in which the end-products biogas and digestates hold similar economic and agroenvironmental importance, organic amendment and fertilizer properties of digestates are critical parameters that could ensure agro-ecosystem sustainability while contributing to the reduction of the dependency towards fossil fuels (reduction of mineral fertilizer consumption). With respect to organic amendment properties, defined as attributes of organic materials that could maintain or improve soil physical, chemical and biological properties, little research is available on the relationships between the biomass input used at the onset of the anaerobic digestion process and the output digestate content in organic matter, dry matter, total carbon and humic substances (humic acids/fulvic acids ratio). Such knowledge would allow the preferential selection of feedstock that result, upon anaerobic digestion, in digestates high in organic matter and humic acids which could be ultimately used as soil conditioner to restore eroded, degraded and disturbed land such as quarry pits, mining fields, landfill sites etc...

\subsection{Long-term effects of solid digestates on soil physical properties}

Unlike classic organic amendments such as manures, composts and sewage sludge, which have been extensively investigated (Khallel et al. 1981; McConnell et al. 1993; Stabnikova et al. 2005; Diacono and Montemurro 2010), little is known about the long-term effects of solid digestates on soil aggregate stability, bulk density, water holding capacity, hydraulic conductivity etc... The organic and dry matter contents as well as cellulose/lignin ratios reviewed in this paper suggest that solid digestates are good candidates for increasing soil aggregation, water holding capacity, hydraulic conductivity and decreasing bulk density. Compounds such as cellulose, lignin and humic substances, which are barely degraded during the anaerobic digestion, are highly reactive and can interact directly with soil surfaces to strengthen the aggregates (Pagliai et al. 1981). Other research questions that can help evaluate the long-term potential of digestates are:

- Long-term effects of land application of digestates on the accumulation and availability of soil nutrients: 
What is the time-course of total $\mathrm{N}$, organic $\mathrm{C}$, available $\mathrm{P}$ and exchangeable $\mathrm{K}$ in soils that have been spread with digestates?

- The cumulative and residual effects of digestate nitrogen on crop growth and quality:

There are little published data available on how nitrogen is released from a single application of digestate or on the accumulated residual effects following repeated applications. This information is pivotal in the reduction of the amount of $\mathrm{N}$ fertilizer required where digestates are applied either on a regular basis onto croplands and rangelands, or as large oneoff applications for land reclamation. Information on the effect of digestates on crop quality is paramount as well. Relationships between digestate rates and crop quality variables have to be investigated. Examples of such dependent quality variables are lodging of cereals and flax, cereal protein content, leaf/cob ratio in silage maize, change in grassland species composition and quality, high nitrate and potassium content and reduced calcium and magnesium contents of grass, sugar content and sap purity in sugar beet $(\mathrm{N}, \mathrm{K}, \mathrm{Na})$ and starch content of potatoes.

\subsection{Identification of specific pathogen indicators to characterize digestate products}

There have been several instances of persistence of pathogenic parasite eggs, bacteria and fungi in biogas plants despite the thermophilic hygienization of the anaerobic process. In particular, L. monocytogenes has been detected in some digestates. Negative detection of some pathogens may be due to unsuitable protocols of pathogen indicators, hence the need to identify specific pathogen indicators in order to characterize digestate products.

\subsection{Determination of emission factors}

Emission factors are defined as the amount of ammonia that volatilize from organic or inorganic sources into the atmosphere. They help estimate the potential adverse impact of the material on the environment as well as the utilization rate of nitrogen by crops. Several field studies have estimated emission factors of various livestock manure (see above). Research on ammonia emission from gas tanks, storage facilities and land applications of anaerobic digestates is needed in order to quantify the environmental risks associated with their use.

\section{Conclusion}

Research on biogas digestates has intensified during the past decade, yet the question of their effectiveness as organic amendment or fertilizer lingered in the mind of many researchers and research users. This review has shown the high variability within the digestate group of organic materials with respect to their physical and biochemical properties. Their biochemical properties, which are a function of the initial biomass inputs, suit the legal requirements on organic amendments of most European countries. Short-term studies have shown that the application of anaerobic digestates onto soils can have positive effects on their physical properties such as reduction of bulk density, increase in saturated hydraulic conductivity and enhancement of moisture retention capacity. Regarding the fertilizer properties of anaerobic digestates, the past decade of research has shown that their efficacies lie between those of livestock manures and mineral fertilizers, with many instances where digestates equalled mineral fertilizers. It is worth mentioning that the fertilizer efficacy of liquid digestates depends upon factors such as the nature of the feedstock (best results when co-digested), the method of storage and handling (e.g. use of protective floating layers and tight membrane-covered tanks) and the method of field applications (best results with injection and trail-shoe methods). However, because of their higher $\mathrm{pH}$ and $\mathrm{NH}_{3} / \mathrm{NH}_{4}$ contents, anaerobic digestates have a higher potential than livestock manures for emitting ammonia and nitrous oxide into the atmosphere. Hence, they can adversely affect air and water quality, as well as contribute to the global warming process of our planet. Anaerobic digestates also pose a long-term threat to soil health through the accumulation of metal elements, mainly $\mathrm{Cu}, \mathrm{Zn}$ and $\mathrm{Mn}$. This scenario is particularly within the realm of possibility in cases of anaerobic co-digestion with cattle and pig slurries. Although some research progress has been accomplished, more specific studies are needed to advance knowledge on anaerobic digestates and their contribution to a sustainable and environmentally sound agriculture. These include the linkage between the nature of the feedstock and the amending properties of the anaerobic digestates, the long-term effects of their applications on soil chemical and physical properties, the identification of suitable pathogen indicator protocols for anaerobic digestates and the determination of their specific emission factors.

\section{References}

Abdullahi YA, Akunna JC, White NA, Hallet PD, Wheatley R (2008) Investigating the effects of anaerobic and aerobic post-treatment on quality and stability of organic fraction of municipal waste as soil amendment. Bioresour Technol 99:8631-8636. doi:10.1016/j. biortech.2008.04.027

Adeli A, Varco JJ, Sistani KR, Rowe DE (2005) Effects of swine lagoon effluent relative to commercial fertilizer applications on warmseason forage nutritive value. Agro J 97:408-417. doi:10.2134/ agronj2005.0408

AFNOR: FD CR 13456 (2001) Amendements du sol et supports de culture-Etiquetage, specifications et listes de produits. 
Association Française de Normalisation, La Plaine Saint-Denis Cedex

Ahmad R, Jabeen N (2009) Demonstration of crop improvement in sunflower (Helianthus annus L.) by the use of organic fertilizers under saline conditions. Pak J Bot 41:1373-1384

Ahring BK (2003) Preface. In: Ahring BK (ed) Biomethanation II. Springer, Berlin

Al Seadi T, Moller HB (2003) Separation of slurry - a potential option for the animal production sector. In: Proceedings of the European biogas workshop "The future of biogas in Europe II". Esbjerg, 2-4 October

Alburquerque JA, de la Fuente C, Ferre-Costa A, Carrasco L, Cegarra J, Abad M, Bernal MP (2012) Assessment of the fertiliser potential of digestates from farm and agro-industrial residues. Biomass Bioenergy 40:181-189. doi:10.1016/j.biombioe.2012.02.018

Amon B, Kryvoruchko V, Amon T, Zechmeister-Boltenstern (2006) Methane, nitrous oxide and ammonia emissions during storage and after application of dairy cattle slurry and influence of slurry treatment. Agric Ecosyst Environ 112:153-162. doi:10.1016/j.agee. 2005.08.030

Amon T, Amon B, Kryvoruchko V, Zollitsch W, Mayer K, Gruber L (2007) Biogas production from maize and dairy cattle manureinfluence of biomass composition on the methane yield. Agric Ecosyst Environ 118:173-182. doi:10.1016/j.agee.2006.05.007

Angelidaki I, Ellegaard L, Ahring BK (2003) Applications of the anaerobic digestion process. In: Ahring BK (ed) Biomethanation II. Springer, Berlin, pp 1-33

Arthurson V (2009) Closing the global energy and nutrient cycles through application of biogas residue to agricultural land - potential benefits and drawbacks. Energies 2:226-242. doi:10.3390/en20200226

Asman WAH (1992) Ammonia emissions in Europe: updated emissions and emission variations. Report no. 228471008. National Institute of Public Health and Environmental Protection, Bilthoven

Asman WAH, Van Jaarsveld HA (1990) Regional and Europe-wide emission and transport of $\mathrm{NH}_{\mathrm{x}}$ compounds. In: Hartung $\mathrm{J}$ et al (eds) Ammoniak in der Unwelt, vol 2. Landwirtschaftswerlad, Munster, pp 1-35

Bachmann S, Wentzel S, Eichier-Löbermann B (2011) Codigested dairy slurry as a phosphorus and nitrogen source for Zea mays L. and Amaranthus cruentus L. J Plant Nutr Soil Sci 174:908-915. doi:10. 1002/jpln.201000383

Bagge E, Sahlstrom L, Albihn A (2005) The effect of hygienic treatment on the microbial flora of biowaste at biogas plants. Water Res 39: 4879-4880. doi:10.1016/j.watres.2005.03.016

Berger KC, Gerloff GC (1947) Manganese toxicity of potatoes in relation to strong soil acidity. Soil Sci Soc Am Proc 12:310-314. doi:10. 2136/sssaj1948.036159950012000C0074x

Bethlenfalvay GJ, Yoder JF (1981) The glycine-glomus-rhizobium symbiosis I. Phosphorus effect on nitrogen fixation and mycorrhizal infection. Physiol Plant 52:141-145. doi:10.1111/j.1399-3054. 1981.tb06047.x

Bicudo JR, Goyal SM (2003) Pathogens and manure management systems: a review. Environ Technol 24:115-130. doi:10.1080/ 09593330309385542

Birkmose T (2009) Nitrogen recovery from organic manures: improved slurry application techniques and treatment - the Danish scenario. International Fertiliser Society, Proceedings 656

Bischofsberger W, Dichtl N, Rosenwinkel KH, Seyfried CF, Böhnke B (2005) Anaerobtechnik, 2nd rev. edn. Springer, Berlin

Bonetta S, Ferretti E, Bonetta S, Fezia G, Carraro E (2011) Microbiological contamination of digested products from anaerobic co-digestion of bovine manure and agricultural by-products. Lett Appl Microbiol 53: 552-557. doi:10.1111/j.1472-765X.2011.03148.x

Börjesson P, Berglund M (2007) Environmental system analysis of biogas systems. Part II: The environmental impact of replacing various reference systems. Biomass Bioenergy 31:326-344. doi: 10.1016/j.biombioe.2007.01.004
Boydston RA, Collins HP, Vaughn SF (2008) Response of weeds and ornamental plants to potting soil amended with dried distillers grains. HortSci 43:191-195

Brenner A, Clemens J (2005) Vergleich der stoffflüsse mit ökologischer bilanzierung von zwei kofermentationsanlagen. Technical report. University of Bonn, Germany. http://www.usl.uni-bonn.de/pdf/ forschungsbericht $\% 20128$.pdf. Accessed 2 Mar 2012

BSI. PAS 110 (2010) Specification for whole digestate, separated liquor and separated fibre derived from the anaerobic digestion of sourcesegregated biodegradable materials. British Standards Institution, London. http://www.wrap.org.uk/sites/files/wrap/PAS110_vis_10. pdf Accessed 03 January, 2013

Buffiere P, Loisel D, Bernet N, Delgenes JP (2006) Towards new indicators for the prediction of solid waste anaerobic digestion properties. Water Sci Technol 53:233-241

Buijsman E, Maas HFM, Asman WAH (1987) Anthropogenic NH3 emissions in Europe. Atmos Environ 21:1009-1022. doi:10.1016/ 0004-6981(87)90230-7

Burgess JE, Quarmby J, Stephenson T (1999) Role of micronutrients in activated sludge-based biotreatment of industrial effluents. Biotechnol Adv 17:49-70. doi:10.1016/S0734-9750(98)00016-0

Burns JC, Westerman PW, King LD, Overcash MR, Cummings GA (1987) Swine manure and lagoon effluent applied to a temperate forage mixture: I. Persistence, yield, quality, and elemental removal. J Environ Qual 16:99-105. doi:10.2134/jeq1987.00472425001600020002x

Campitelli P, Ceppi S (2008) Effects of composting technologies on the chemical and physiochemical properties of humic acids. Geoderma 144:325-333. doi:10.1016/j.geoderma.2007.12.003

Canali S, Bartolomeo ED, Tittarelli F, Montemurro F, Verrastro V, Ferri D (2011) Comparison of different laboratory incubation procedures to evaluate nitrogen mineralization in soil amended with aerobic and anaerobic stabilized organic materials. J Food Agric Environ 9:540 546

Chambers BJ, Smith KA, van der Weerden TJ (1997) Ammonia emissions following the land spreading of solid manures. In: Jarvis SC, Pain BF (eds) Gaseous nitrogen emissions from grasslands. CAB International, Oxford, pp 275-280

Chantigny MH, Rochette P, Angers DA, Massé D, Côté D (2004) Ammonia volatilization and selected soil characteristics following application of anaerobically digested pig slurry. Soil Sci Soc Am J 68:306-312. doi:10.2136/sssaj2004.3060

Chantigny MH, Angers DA, Belanger G, Rochette P, Masse D, Cote D (2007) Gaseous N emissions and forage N uptake on soils fertilized with raw and treated swine manure. J Environ Qual 36:1864-1872. doi:10.2134/jeq2007.0083

Chantigny MH, Angers DA, Belanger G, Rochette P, Eriksen-Hamel N, Bittman S, Buckley K, Masse D, Gasser M-O (2008) Yield and nutrient export of grain corn fertilized with raw and treated liquid swine manure. Agron J 100:1303-1309. doi:10.2134/agronj2007.0361

Chesworth W (1991) Geochemistry of micronutrients. In: Mortvedt JJ, Cox FR, Shuman LM, Welch RM (eds) Micronutrients in agriculture. Soil Science Society of America, Madison, pp 96-99

Chynoweth DP, Isaacson R (1987) Anaerobic digestion of biomass. Elsevier, Barking

Civil Engineering Research Institute of Hokkaido (2003) Research report of environment, resources, and recycling in Hokkaido, Sapporo. Civil Engineering Institute of Hokkaido, Sapporo (in Japanese)

Clark RB (1982) Plant response to mineral element toxicity and deficiency. In: Christiansen MN, Lewis CF (eds) Breeding plants for less favorable environments. Wiley, New York, pp 71-142

Clemens J, Morton RH (1999) Optimizing mineral nutrition for flower production in Heliconia "Golden Torch" using response surface methodology. J Amerc Soc Hortic Sci 124:713-718

Colleran E (2000) Hygienic and sanitation requirements in biogas plants treating animal manures or mixtures of manures and other organic wastes. In: Orthenblad H (ed) Anaerobic digestion: making energy 
and solving modern waste problems. Herning Municipal Authorities, Denmark, pp 77-86

Collins HP, Alva AK, Steubel JD, Fransen SF, Frear C, Chen S, Kruger C, Granatstein D (2011) Greenhouse gas emissions from an irrigated silt loam soil amended with anaerobically digested dairy manure. Soil Sci Soc Am J 75:2206-2216. doi:10.2136/sssaj2010.0360

Damgaard PH, Børsting CE, Rom HB, Sommer SG (2001) Kvaelstof, fosfor og kalium I husdyrgødning- normtal 2000. (In Danish) (Nitrogen, phosphorus and potassium in animal manure-norms 2000). DJF rapport Husdyrbrug nr. 36

Denman KL, Brasseur G, Chidthaisong A, Ciais P, Cox PM, Dickinson RE et al (2007) Climate Change 2007: the physical science basis. Contribution of Working Group III to the Fourth Assessment Report of the Intergovernmental Panel on climate Change. Cambridge University Press, Cambridge

DeVleeschauwer D, Verdonck O, Van Assche P (1981) Phytotoxicity of refuse compost. BioCycle 22:44-46

Diacono M, Montemurro F (2010) Long-term effect of organic amendments on soil fertility. A review. Agron Sustain Dev 30:401-422. doi:10.1051/agro/2009040

Doran JW, Parkin TP (1994) Defining and assessing soil quality. In: Doran JW, Coleman DC, Bezdicek DF, Stewart BA (eds) Defining soil quality for sustainable environment. American Society of Agronomy special publication. American Society of Agronomy, Madison, pp 3-21

Dragosits U, Theobald MR, Place CJ, Lord E, Webb J, Hill J, ApSimon HM, Sutton MA (2002) Ammonia emission, deposition and impact assessment at the field scale: a case study of sub-grid spatial variability. Environ Pollut 117:147-158. doi:10.1016/S0269-7491(01) 00147-6

Drennan MF, Distefano TD (2010) Characterization of the curing process from high solids anaerobic digestion. Biores Technol 101:537-544. doi:10.1016/j.biortech.2009.08.029

EA (2009) Anaerobic digestates. Waste Protocols Project. Environment Agency, Rotherham. Available from: http://www.environmentagency.gov.uk/static/documents/Business/Financial_impact assessment for anaerobic digestate.pdf. Accessed on $18 \overline{\mathrm{Mar}} 201 \overline{2}$

Ebbs SD, Kochian LV (1997) Toxicity of zinc and copper to Brassica species: implications for phytoremediation. J Environ Qual 26:776781. doi:10.2134/jeq1997.00472425002600030026x

Edelmann W, Baier U, Engeli H (2004) Environmental aspects of the anaerobic digestion of the organic fraction of municipal solid wastes and of agricultural wastes. Water Sci Technol 52:203-208

El-Jaoual T, Cox DA (1998) Manganese toxicity in plants. J Plant Nutr 21:353-386. doi:10.1080/01904169809365409

El-Shakweer MHA, El-Sayad EA, Ewees MSA (1998) Soil and plant analysis as a guide for the interpretation of the improvement efficiency or organic conditioners added to different soils in Egypt. Commun Soil Sci Plant 29:2067-2088. doi:10.1080/ 00103629809370094

EPA (2004) What is visibility impairment? United States Environmental Protection Agency, Washington, DC. Available at: www.epa.gov/ oar/visibility/what.html. Accessed 12 Jul 2012

Epstein E (1961) Mineral metabolism of halophytes. In: Rorison IH (ed) Ecological aspects of the mineral nutrition of plants. Blackwell, Oxford, pp 345-353

Erisman JW, Monteny GJ (1998) Consequences of new scientific findings for future abatement of ammonia emissions. Environ Pollut 102:275-282. doi:10.1016/S0269-7491(98)80044-4

Esteban RL, Sawyer JE (2005) Extractable soil phosphorus and inorganic nitrogen following application of raw and anaerobically digested swine manure. Agron J 97:879-885. doi:10. 2134/agronj2004.0249

Fangmeier A, Hadwiger-Fangmeier A, Van der Eerden L, Jäger H (1994) Effects of atmospheric ammonia on vegetation - a review. Environ Pollut 86:43-82. doi:10.1016/0269-7491(94)90008-6
Fouda S (2011) Nitrogen availability of biogas residues. Ph.D. thesis, Technische Universitat Munchen

Furukawa Y, Hasegawa H (2006) Response of spinach and Komatsuna to biogas effluent made from source-separated kitchen garbage. J Environ Qual 35:1939-1947. doi:10.2134/jeq2005.0482

Gantzer C, Gaspard P, Galvez L, Huyard A (2001) Monitoring of bacteriological and parasitological contamination during various treatment of sludge. Water Res 35:3763-3770. doi:10.1016/S00431354(01)00105-1

Garg RN, Pathak H, Das DK, Tomar RK (2005) Use of fly ash and biogas slurry for improving wheat yield and physical properties of the soil. Environ Monit Assess 107:1-9. doi:10.1007/s10661-005-2021-x

Gell K, van Groenigen J, Cayuela ML (2011) Residues of bioenergy production chains as soil amendments: immediate and temporal phytotoxicity. J Hazard Mat 186:2017-2025. doi:10.1016/j. jhazmat.2010.12.105

Gericke D (2009) Measuring and modeling of ammonia emissions after field application of biogas slurries. Doctoral thesis, Kiel University, Germany

Goberna M, Insam H, Franke-Whittle IH (2009) Effect of biowaste sludge maturation on the diversity of thermophilic bacteria and archaea in an anaerobic reactor. Appl Environ Microbiol 75:25662570. doi:10.1128/AEM.02260-08

Goberna M, Podmirseg SM, Waldhuber S, Knapp BA, Garcia C, Insam H (2011) Pathogenic bacteria and mineral $N$ in soils following the land spreading of biogas digestates and fresh manure. Appl Soil Ecol 49: 18-25. doi:10.1016/j.apsoil.2011.07.007

Gomez X, Cuetos MJ, Garcia AI, Moran A (2005) Evaluation of digestate stability from anaerobic process by thermogravimetric analysis. Thermochim Acta 426:179-184. doi:10.1016/j.tca.2004.07.019

Gomez X, Cuetos MJ, Garcia AI, Moran A (2007) An evaluation of stability by thermogravimetric analysis of digestate obtained from different biowastes. J Hazard Mater 149:97-105. doi:10.1016/j. jhazmat.2007.03.049

Gong W, Yan X, Wang J, Hu T, Gong Y (2011) Long-term application of chemical and organic fertilizers on plant-available nitrogen pools and nitrogen management index. Biol Fertil Soils 47:767-775. doi: 10.1007/s00374-011-0585-x

Goodroad LL, Keeney DR (1984) Nitrous oxide emissions from soil during thawing. Can J Soil Sci 64:187-194. doi:10.4141/cjss84-020

Gorsuch JW, Kringle RO, Robillard KA (1990) Chemical effects on the germination and early growth of terrestrial plants. ASTM special technical publication, pp 49-58

Gough RE, Carlstrom R (1999) Wheat gluten meal inhibits germination and growth of broadleaf and grassy weeds. HortSci 34:269-270

Goulding KWT, Bailey NJ, Bradbury NJ, Hargreaves P, Howe M, Murphy DV, Poulton PR (1998) Nitrogen deposition and its contribution to nitrogen cycling and associated soil processes. New Phytol 139:49-58. doi:10.2307/2588247

Grewal SK, Rajeev S, Sreevatsan S, Michel FC (2006) Persistence of Mycobacterium avium subsp. Paratuberculosis and other zoonotic pathogens during simulated composting, manure packing, and liquid storage of dairy manure. Appl Environ Microbial 72:565-574

Gutser R, Ebertseder T, Weber A, Schraml M, Schmidhalter U (2005) Short-term and residual availability of nitrogen after long-term application of organic fertilizers on arable land. J Plant Nutr Soil Sci 168:439-446. doi:10.1002/jpln.200520510

Hachida S, Sellami F, Cegarra J, Hachida R, Drira N, Medhhioub K, Ammar E (2009) Biological activity during co-composting of sludge issued from OMW evaporation ponds with poultry manure. Physico-chemical characterization of the processed organic matter. J Hazard Mater 162:402-409. doi:10.1016/j.jhazmat.2008.05.053

Hao X, Chang C, Janzen HH, Hill BR, Ormann T (2005) Potential nitrogen enrichment of soil and surface water by atmospheric ammonia sorption in intensive livestock production areas. Agric Ecosyst Environ 110:185-194. doi:10.1016/j.agee.2005.04.002 
Hao X, Chang C, Janzen HH, Clayton G, Hill BR (2006) Sorption of atmospheric ammonia by soil and perennial grass downwind from two large cattle feedlots. J Environ Qual 35:1960-1965. doi:10. 2134/jeq2005.0308

Haraldsen TK, Andersen U, Krogstad T, Sørheim R (2011) Liquid digestate from anaerobic treatment of source-separated household waste as fertilizer to barley. Waste Manag Res 29:1271-1276. doi: 10.1177/0734242X11411975

Hasegawa H, Furukawa Y, Kimura SD (2005) On-farm assessment of organic amendments effects on nutrient status and nutrient use efficiency of organic rice fields in Northeastern Japan. Agric Ecosyst Environ 108:350-362. doi:10.1016/j.agee.2004.12.015

Hatfield JL, Stewart BA (2002) Animal wastes utilization: effective use of manure as a soil resource. CRC, Boca Raton

Havlin JL, Kissel DE, Maddux LD, Claassen MM, Long JH (1990) Crop rotation and tillage effects on soil organic carbon and nitrogen. Soil Sci Soc Amer J 54:448-452. doi:10.2136/sssaj1990. $03615995005400020026 x$

Hengnirun S, Barrington S, Prasher SO, Lyew D (1999) Development and verification of a model simulating ammonia volatilization from soil and manure. J Environ Qual 28:108-144. doi:10.2134/jeq1999. $00472425002800010012 x$

Herrmann A, Sieling K, Wienforth B, Taube F, Kage H (2013) Short-term effects of biogas residue application on yield performance and $\mathrm{N}$ balance parameters of maize in different cropping systems. J Agric Sci 151:449-462. doi:10.1017/S0021859612000548

Holm-Nielsen JB, Al Seadi T, Oleskowicz-Popiel P (2009) The future of anaerobic digestion and biogas utilization. Bioresour Technol 100: 5478-5480. doi:10.1016/j.biortech.2008.12.046

Horst WJ (1988) The physiology of Mn toxicity. In: Graham RD, Hannam RJ, Uren NC (eds) Manganese in soils and plants. Kluwer Academic, Dordrecht, pp 175-188

Hubbard RK, Lowrance RR (1998) Dairy cattle manure management. In: Agricultural utilization of municipal, animal and industrial wastes. USDA, Agric. Res. Service, Conservation Res. Rep. No. 44. USDA, Washington, DC, pp 91-100

Huisjsmans JFM, Hol JMG, Hendriks MMW (2002) Effect of application techniques, manure characteristics, weather and field conditions on ammonia volatilization from manure applied to grassland. Neth $\mathrm{J}$ Agric Sci 49:323-342. doi:10.1016/S1573-5214(01)80021-X

Hutchison ML, Walters LD, Avery SM, Munro F, Moore A (2005) Analysis of livestock production, waste storage, and pathogen levels and prevalences in farm manures. Appl Environ Microbiol 71: 1231-1236. doi:10.1128/AEM.71.3.1231-1236.2005

Iakimenko O, Otabbong E, Sadovnikova L, Persson J, Nilsson I, Orlov D, Ammosova Y (1996) Dynamic transformation of sewage sludge and farmyard manure components. 1. Content of humic substances and mineralization of organic carbon and nitrogen in incubated soils. Agric Ecosyst Environ 58:121-126. doi:10.1016/0167-8809(95) 01006-8

IEA (2010) Utilisation of digestate from biogas plants as biofertiliser. International Energy Agency, IEA Bioenergy Task 37, Paris

Inglet GE, Rose DJ, Stevenson DG, Chen D, Biswas A (2009) Total phenolic and antioxidant activity of water and ethanolic extracts from distillers dried grains with solubles with or without microwave irradiation. Cereal Chem 86:661-664. doi:10.1094/CCHEM-86-60661

Israel DW (1987) Investigation of the role of phosphorus in symbiotic dinitrogen fixation. Plant Physiol 84:835-840. doi:10.1104/pp. 84. 3.835

Jacobs LW (1981) Agricultural application of sewage sludge. In: Norchardt JA (ed) Sludge and its ultimate disposal. Ann Arbor Science, Ann Arbor, pp 109-126

Jacobson HGM, Swanback TR (1932) Manganese content of certain Connecticut soils and its relation to the growth of tobacco. J Am Soc Agron 24:237-245
Jäkel K, Mau S (1999) Umweltwirkung von biogasgülle. Abschlußbericht zum forschungs-projekt, Dresden. https:// publikationen.sachsen.de/bdb/artikel/15244/documents/18424. Accessed 3 Oct 2013

Jarvis SC, Pain BF (1990) Ammonia volatilization from agricultural land. Proceedings 298. The Fertilizer Society, Peterborough

Jenkinson DS, Andrew SPS, Lynch JM, Goss MJ, Tinker P (1990) The turnover of organic carbon and nitrogen in soil. Phil Trans R Soc London Ser B 329:361-368

Jørgensen U, Petersen BM (2006) Interactions between biomass energy technologies and nutrient and carbon balances at the farm level. In: Petersen SO (ed) Proc. $12^{\text {th }}$ Ramiran Int. Conf., pp 4956

Kamprath EJ, Foy CD (1971) Lime-fertilizer-plant interactions in acid soils. In: Olson RA, Army TJ, Hanway JJ, Kilmer VJ (eds) Fertilizer technology and use. Soil Science Society of America, Madison, pp 105-141

Kaparaju P, Rintala J, Oikari A (2012) Agricultural potential of anaerobically digested industrial orange waste with and without aerobic post-treatment. Environ Technol 33:85-94

Khallel R, Reddy KR, Overcash MR (1981) Changes in soil physical properties due to organic waste applications: a review. J Environ Qual 10:133-141. doi:10.2134/jeq1981.00472425001000020002x

Kirchmann H, Bernal MP (1997) Organic waste treatment and C stabilization efficiency. Soil Biol Biochem 29:1747-1753. doi:10.1016/ S0038-0717(97)00065-5

Kluge R, Wagner W, Mokry M, Dederer M et al (2008) Final report of the project "Inhaltsstoffe von Garprodukten und Moglichkeiten zu ihrer geordneten landwirtschaftlichen Verwertung". http://www. landwirtschaftmlr.badenwuerttemberg.de/servlet/PB/show/ 1235603 11/ltz Projektbericht. Accessed Feb 2009

Komilis DP, Ham RK (2003) The effects of lignin and sugars to the aerobic decomposition of solid wastes. Waste Manag 23:419-423. doi:10.1016/S0956-053X(03)00062-X

Krupa SV (2003) Effects of atmospheric ammonia $\left(\mathrm{NH}_{3}\right)$ on terrestrial vegetation: a review. Environ Pollut 124:179-221. doi:10.1016/ S0269-7491(02)00434-7

Kruse M, ApSimon HM, Bell JNB (1989) Validity and uncertainty in the calculation of an emission inventory for ammonia arising from agriculture in Great Britain. Environ Pollut 56:237-257. doi:10. 1016/0269-7491(89)90040-7

Lafleur B, Thiffault E, Pare D, Camire C, Bernier-Cardou M, Masse S (2012) Effects of hog manure application on the nutrition and growth of hybrid poplar (Populus spp.) and on soil solution chemistry in short-rotation woody crops. Agric Ecosyst Environ 155:95104. doi:10.1016/j.agee.2012.04.002

Lam VT, Watanabe T, Phan TT, Khai LTL (2002) A case study: introduction of low-cost biogas digester to small-case farming systems. Japan International Research Centre for Agricultural Sciences (JIRCAS). Working report 26, pp 65-72

Larsen T, Luxhoi J, Magid J, Jensen LS, Krogh PH (2007) Properties of anaerobically digested and composted municipal solid waste assessed by linking soil mesofauna dynamics and nitrogen modeling. Biol Fertil Soils 44:59-68. doi:10.1007/s00374-007-0178-x

Leege PB, Thompson WH (1997) Test methods for the examination of composting and compost. The US Composting Council, Bethesda

Lemke RL, Izaurralde RC, Malhi SS, Arsha MA, Nyborg M (1998) Nitrous oxide emissions from agricultural soils of the boreal and parkland regions of Alberta. Soil Sci Soc Am J 62:1096-1102. doi: 10.2136/sssaj1998.03615995006200040034x

Liu D, Christians N (1994) Isolation and identification of root-inhibiting compounds from corn gluten hydrolysate. J Plant Growth Regul 13: 227-230. doi:10.1007/BF00226041

Loria ER, Sawyer JE (2005) Extractable soil phosphorus and inorganic nitrogen following application of raw and anaerobically digested swine manure. Agron J 97:879-885. doi:10.2134/agronj2004.0249 
Loria ER, Sawyer JE, Barker DW, Lundvall JP, Lorimor JC (2007) Use of anaerobically digested swine manure as a nitrogen source in corn production. Agron J 99:1119-1129. doi:10.2134/agronj2006.0251

Luste S, Luostarinen S (2010) Anaerobic co-digestion of meat-processing by-products and sewage sludge. Effect of hygienization and organic load rate. Bioresour Technol 101:2657-2664. doi:10.1016/j. biortech.2009.10.071

MAFF (1995) Fertiliser recommendations for agricultural and horticultural crops (RB209), 6th edn. MAFF, Her Majesty's Stationery Office, London

Marschner H (1995) Mineral nutrition of higher plants, 2nd edn. Academic, San Diego

Martin JH (2004) A Comparison of Dairy Cattle Manure Management with and without Anaerobic Digestion and Biogas Utilization. Report for the AgSTAR Program, U.S. Environmental Protection Agency, 2004, pp. 58. Available at: http://www.ncgreenpower.org/ documents/nydairy2003.pdf. Accessed 18 Jan 2013

Masse D, Gilbert Y, Topp E (2011) Pathogen removal in farm-scale psychrophilic anaerobic digesters processing swine manure. Bioresour Technol 102:641-646. doi:10.1016/j.biortech.2010.08.020

Matsunaka T, Sawamoto T, Ishimura H, Takakura K, Takekawa A (2006) Efficient use of digested cattle slurry from biogas with respect to nitrogen recycling in grassland. Int Congr Ser 1293:242-250

Mattila PK, Joki-Tokola E, Tanni R (2003) Effect of treatment and application technique of cattle slurry on its utilization by ley: II. Recovery of nitrogen and composition of herbage yield. Nutr Cycl Agroecosyst 65:231-242

McConnell DD, Shiralipour A, Smith WH (1993) Compost application improves soil physical properties. Biocycles 34:61-63

McLachlan KL, Chong C, Voroney RP, Liu HW, Holbein BE (2004) Assessing the potential phytotoxicity of digestates during processing of municipal solid waste by anaerobic digestion; a comparison to aerobic digestion. In: Bertschinger L, Anderson JD (eds) Sustainability of horticultural systems, Acta Hort (ISHS) 638, pp 225-230

McMurry PH, Takano H, Anderson GR (1983) Study of the ammonia (gas)-sulphuric acid (aerosol) reaction rate. Environ Sci Technol 17: 347-352. doi:10.1021/es00112a008

Metz B, Davidson OR, Bosh PR, Dave R, Meyer LA (2007) Climate change 2007: mitigation. Contribution of working group III to the Fourth Assessment Report of the Intergovernmental Panel on Climate Change. Cambridge University Press, Cambridge

Michalzik B, Kalbitz K, Park JH, Solinger S, Matzner E (2001) Fluxes and concentrations of dissolved organic carbon and nitrogen - a synthesis for temperate forests. Biogeochem 52:173-205

Misselbrook TH, Van Der Weerden TJ, Pain BF, Jarvis SC, Chambers BJ, Smith KA, Phillips VR, Demmers TGM (2000) Ammonia emission factors for UK agriculture. Atmos Environ 34:871-880. doi:10. 1016/S1352-2310(99)00350-7

Möller K, Müller T (2012) Effects of anaerobic digestion on digestate nutrient availability and crop growth: a review. Eng Life Sci 12:242 257. doi:10.1002/elsc.201100085

Möller K, Stinner W (2009) Effects of different manuring systems with and without biogas digestion on soil mineral nitrogen content and on gaseous nitrogen losses (ammonia, nitrous oxides). Eur J Agron 30: 1-16. doi:10.1016/j.eja.2008.06.003

Möller K, Stinner W, Deuker A, Leithold G (2008) Effects of different manuring systems with and without biogas digestion on nitrogen cycle and crop yield in mixed organic farming systems. Nutr Cycl Agroecosyst 82:209-232. doi:10.1007/s10705-008-9196-9

Möller K, Schulz R, Müller T (2010) Substrate inputs, nutrient flows and nitrogen loss of two centralized biogas plants in southern Germany. Nutr Cycl Agroecosyst 87:307-325. doi:10.1007/s10705-0099340-1

Morris HD, Pierre WH (1947) The effect of calcium, phosphorus, and iron on the tolerance of lespediza to manganese toxicity in culture solutions. Proc Soil Sci Soc Am 12:382-386
Mosier AR, Kroeze C, Nevison C, Oenema O, Seitzinger S, van Cleemput O (1998a) Closing the global $\mathrm{N}_{2} \mathrm{O}$ budget: nitrous oxide emissions through the agricultural nitrogen cycle. Nutr $\mathrm{Cycl}$ Agroecosyst 52:225-248. doi:10.1023/A:1009740530221

Mosier AR, Duxbury JM, Freney JR, Heinemeyer O, Minami K (1998b) Assessing and mitigating $\mathrm{N}_{2} \mathrm{O}$ emissions from agricultural soils. Climate Change 40:7-38. doi:10.1023/A:1005386614431

Mshandete A, Bjornssona L, Kivaisi AK, Rubindamayugi ST, Mattiasson B (2005) Enhancement of anaerobic batch digestion of sisal pulp waste by mesophilic aerobic pre-treatment. Water Res 39:1575. doi: 10.1016/j.watres.2004.11.037

Mulla DJ, Birr AS, Randall G, Moncerief J, Schmitt M, Sekely A, Kerre E (2001) Impacts of animal agriculture on water quality: technical work paper. Minnesota Environmental Quality Board, Minnesota Planning (Agency), St. Paul

Murto M, Bjornsson L, Mattiasson B (2004) Impact of food industrial waste on anaerobic co-digestion of sewage sludge and pig manure. J Environ Manag 70:101-107. doi:10.1016/j.jenvman.2003. 11.001

Newton GL, Hubbard RK, Johnson JC, Davis JG, Vellidis G, Lowrance R, Johnson AW, Williams RG, Dove CR (1994) Utilization and environmental consequences of land application of liquid manure in the southeastern United States coastal plain. In: Proc. Great Plains Anim. Waste Conf. Confined Anim. Prod. Water Quality. Balancing Anim. Prod. and the Environ. Great Plains Agric. Council publ. no. 151, pp 66-73

Ni K, Pacholski A, Gericke D, Kage H (2012) Analysis of ammonia losses after application of biogas slurries by an empirical model. J Plant Nutr Soil Sci 175:253-264. doi:10.1002/jpln.201000358

Nicholson FA, Chambers BJ, Smith KA (1996) Nutrient composition of poultry manures in England and Wales. Bioresour Technol 58:279 284. doi:10.1016/S0960-8524(97)86087-7

Nkoa R, Coulombe J, Desjardins Y, Tremblay N (2001) Towards optimization of growth via nutrient supply phasing: nitrogen supply phasing increases broccoli (Brassica oleracea var italica) growth and yield. J Exp Bot 52:821-827

NRC (2002) Air emissions from animal feeding operations: current knowledge, future needs. Final report, National Research Council. The National Academies, Washington, DC

Ökologischen L, Bodenschutz (2008) Einsatz von Garresten aus der Biogasproduktion als Dungemittel. LfL-Information, Institut fur Agrarokologie

Odgers E (1991) Regulations bolster voluntary programs for cleanup of agricultural nonpoint "bad actors" in Wisconsin. In: National livestock, poultry and aquaculture waste management: Proc. Natl. Workshop. ASAE Publ. 03-92. ASAE, St. Joseph, pp 273-277

Odlare M, Pell M, Svensson K (2008) Changes in soil chemical and microbiological properties during 4 years of application of various organic residues. Waste Manag 28:1246-1253. doi:10.1016/j. wasman.2007.06.005

Oenema O, Tamminga S (2005) Nitrogen in global animal production and management options for improving nitrogen use efficiency. Sci China Ser C Life Sci 48:871-887

Olsen JE, Larsen H (1987) Bacterial decimation times in anaerobic digestions of animal slurries. Biol Wastes 21:153-168. doi:10. 1016/0269-7483(87)90121-2

Olsen JE, Jorgensen JB, Nansen (1985) On the reduction of Mycobacterium avium subsp. Paratuberculosis in bovine slurry subjected to batch mesophilic or thermophilic anaerobic-digestion. Agric Wastes 13:273-280. doi:10.1016/0141-4607(85)90052-6

Ottoson JR, Schnurer A, Vinneras B (2008) In situ ammonia production as a sanitation agent during anaerobic digestion at mesophilic temperature. Lett Appl Microbiol 46:325-330. doi:10.1111/j.1472765X.2007.02317.X

Paavola T, Rintala J (2008) Effects of storage on characteristics and hygienic quality of digestates from four co-digestion concepts of 
manure and biowaste. Bioresour Technol 99:7041-7050. doi:10. 1016/j.biortech.2008.01.005

Pagliai M, Guidi G, Lamarca M, Giachetti M, Luchamante G (1981) Effects of sewage sludges and composts on soil porosity and aggregation. J Environ Qual 10:556-561. doi:10.2134/jeq1981. $00472425001000040028 x$

Pahlsson AMB (1989) Toxicity of heavy metals $(\mathrm{Cu}, \mathrm{Zn}, \mathrm{Cd}, \mathrm{Pb})$ to vascular plants. Wat Air Pollut 47:287-319. doi:10.1007/ BF00279329

Pain BF, Misselbrook TH, Clarkson CR, Rees YJ (1990) Odour and ammonia emissions following the spreading of anaerobically digested pig slurry on grassland. Biol Wastes 34:259-267. doi:10. 1016/0269-7483(90)90027-P

Parawira W, Murto M, Zvauya R, Mattiasson B (2004) Anaerobic batch digestion of solid potato waste alone and in combination with sugar beet leaves. Renew Energy 29:1811-1823. doi:10.1016/j.renene. 2004.02.005

Pell AN (1997) Manure and microbes: public and animal health problem? J Dairy Sci 80:2673-2681. doi:10.3168/jds.S0022-0302(97)76227-1

Pepper IL, Brooks JP, Gerba CP (2006) Pathogens in biosolids. Adv Agron 90:1-41. doi:10.1016/S0065-2113(06)90001-7

Petersen SO (1999) Nitrous oxide emissions from manure and inorganic fertilizers applied to spring barley. J Environ Qual 28:1610-1618. doi:10.2134/jeq1999.00472425002800050027x

Pitcairn CER, Leith ID, Sheppard LJ, Sutton MA, Fowler D, Munro RC, Tang S, Wilson D (1998) The relationship between nitrogen deposition, species composition and foliar nitrogen concentrations in woodland flora in the vicinity of livestock farms. Environ Pollut 102:41-48. doi:10.1016/S0269-7491(98)80013-4

Plymforshell L (1995) Survival of salmonellas and Ascaris suum eggs in a thermophilic biogas plant. Acta Vet Scand 36:79-85

Pötsch EM (2004) Abschlussbericht zum Forschungsprojekt BAL 2941. Nährstoffgehalt von Gärrückständen aus landwirtschaftlichen Biogasanlagen und deren Einsatz im Dauergrünland - Nutrient content of fermentation residues from agricultural biogas systems and their utilization on permanent grassland. http://www.raumberggumpenstein.at/c/index.php?option $=\mathrm{com}$ docman\&task $=\mathrm{doc}$ view\&gid $=1442 \&$ itemid $=100014$. Accessed 3 Oct 2013

Poetsch EM, Pfundtner E, Much P (2004) Nutrient content and hygienic properties of fermentation residues from agricultural biogas plants. In: Lúscher A, Kessler W, Huguenin O, Lobsiger M, Millar N, Suter $\mathrm{D}$ (eds) Land use systems in grassland dominated regions. Proceedings of the 20th General Meeting of the European Grassland Federation, Luzern, Switzerland, 21-24 June 2004, pp. $1055-1057$

Poggi-Varaldo J, Trejo-Espino G, Fernandez-Villagomez G, EsparzaGarcia F, Caffarel-Mendez S, Rinderknecht-Seijas N (1999) Quality of anaerobic compost from paper mill and municipal solid wastes for soil amendment. Water Sci Technol 40:179-186. doi:10. 1016/S0273-1223(99)00716-7

Poole HA, Sheehnan TJ (1980) Mineral nutrition of orchids. In: Arditti J (ed) Orchid biology: reviews and perspectives II. Cornell University Press, Ithaca, pp 197-211

PRE/630/2011 (2011) Orden de 23 de marzo, por la que se modifican los anexos I, II, III, IV, V, y VI del Real Decreto 824/2005, de 8 de junio, sobre productos fertilizantes. BOE 2011 72:31871-31910

Provenzano MR, Iannuzi G, Fabbri C, Senesi N (2011) Qualitative characterization and differentiation of digestates from different biowastes using FTIR and fluorescence spectroscopies. J Environ Prot 2:83-89. doi:10.4236/jep.2011.21009

Qi X, Zhang S, Wang Y, Wang R (2005) Advantages of the integrated pig-biogas-vegetable greenhouse system in North China. Ecol Eng 24:177-185. doi:10.1016/j.ecoleng.2004.11.001

Ravishankara AR, Daniel JS, Portmann RW (2009) Nitrous oxide $\left(\mathrm{N}_{2} \mathrm{O}\right)$ : the dominant ozone-depleting substance emitted in the 21 st century. Science 326:123-125. doi:10.1126/science. 1176985
Reddacliff LA, Vidali A, Whittington RJ (2003) The effect of decontamination protocols on the number of sheeps strain Mycobacterium avium subsp. Paratubercolosis isolated from tissues and faeces. Vet Microbiol 95:271-282. doi:10.1016/S0378-1135(03)00181-0

Risk N, Snider D, Wagner-Riddle C (2013) Mechanisms leading to enhanced soil nitrous oxide fluxes induced by freeze-thaw cycles. Can J Soil Sci 93:401-414. doi:10.4141/cjss2012-071

Rivard CJ, Rodriguez JB, Nagle NJ, Self JR, kay BD, Soltanpour PN, Nieves RA (1995) Anaerobic digestion of municipal solid waste. Appl Biochem Biotechnol 51(52):125-135. doi:10.1007/ BF02933417

Robson AD, O'Hara GW, Abbott LK (1981) Involvement of phosphorus in nitrogen fixation by subterranean clover (Tritifolium subterraneum L.). Aust J Plant Physiol 8:427-436. doi:10.1071/ PP9810427

Rochette P, van Bochov E, Prevost D, Angers DA, Cote D, Bertrand N (2000) Soil carbon and nitrogen dynamics following application of pig slurry for the $19^{\text {th }}$ consecutive years: II. Nitrous oxide fluxes and mineral nitrogen. Soil Sci Soc Am J 64:1396-1403. doi:10.2136/ sssaj2000.6441396x

Rubaek GH, Henriksen K, Petersen J, Rasmussen B, Sommer SG (1996) Effects of application technique and anaerobic digestion on gaseous loss from animal slurry applied to ryegrass (Lolium perenne). J Agric Sci 126:481-492. doi:10.1017/S0021859600075572

Ryden JC, Whitehead DC, Lockyer DR, Thompson RB, Skinner JH, Garwood EA (1987) Ammonia emission from grassland and livestock production systems in the UK. Environ Pollut 48:173-184. doi:10.1016/0269-7491(87)90032-7

Sahlstrom L (2003) A review of survival of pathogenic bacteria in organic waste used in biogas plants. Bioresour Technol 87:161-166. doi:10. 1016/S0960-8524(02)00168-2

Sahlstrom L, Aspan A, Bagge E, Danielsson-Tham ML, Albihn A (2004) Bacterial pathogen incidences in sludge from Swedish sewage treatment plants. Water Res 38:1989-1990. doi:10.1016/j.watres.2004.01.031

Sahm H (1981) Biologie der Methan-Bildung (Biology of methane formation). Chemie Ingenieur Technik 53:854-863. doi:10.1002/ cite. 330531105

Sanchez M, Gomez X, Barriocanal G, Cuetos MJ, Moran A (2008) Assessment of the stability of livestock farm wastes treated by anaerobic digestion. Int Biodeterior Biodegrad 62:421-426. doi: 10.1016/j.ibiod.2008.04.002

Sandars DL, Audsley E, Caňete C, Cumby TR, Scotford IM, Williams AG (2003) Environmental benefits of livestock manure management practices and technology by life cycle assessment. Biosyst Eng 84:267-270. doi:10.1016/S1537-5110(02)00278-7

Sanderson MG, Collins WJ, Johnson CE, Derwent RG (2006) Present and future acid deposition to ecosystems: the effect of climate change. Atmos Environ 40:1275-1283. doi:10.1016/j.atmosenv.2005.10.031

Schattauer A, Abdoun E, Weiland P, Plöchl M, Heiermann M (2011) Abundance of trace elements in demonstration biogas plants. Biosyst Eng 108:57-65. doi:10.1016/j.biosystemseng.2010.10.010

Schievano A, Adani F, Tambone F, D’Imporzano G, Scaglia B, Genevini PL (2009) What is digestate? In: Adani F, Schievano A, Boccasile G (eds) Anaerobic digestion: opportunities for agriculture and environment. Lombardia, Milan, pp 7-18

Schnurer A, Schnurer J (2006) Fungal survival during anaerobic digestion of organic household waste. Waste Manag 26:1205-1211. doi: 10.1016/j.wasman.2005.09.007

Sidhu J, Gibbs RA, Ho GE, Unkovitch I (2001) The role of indigenous microorganisms in suppression of Salmonella regrowth in composted biosolids. Water Res 35:913-920. doi:10.1016/S00431354(00)00352-3

Siebert S (2008) Quality requirements and quality assurance of digestion residuals in Germany. In: ECN/ORBIT workshop The Future of Anaerobic Digestion of Organic Waste in Europe. Nuremberg, Germany 
Siebert S, Thelen-Jüngling M, Kehres B (2008) Development of quality assurance and quality characteristics of composts and digestates in Germany. In: Rodic-Wiersma L, Barth J, Bidlingmaier W, de Bertoldi M, Diaz LF (eds) $6^{\text {th }}$ International conference ORBIT 2008-Moving Organic Waste Recycling Towards Resource Management and Biobased Economy. Wageningen, the Netherlands, October 13-15, 2008, pp 1-12

Slana I, Pribylova R, Kralova A, Pavlik I (2011) Persistence of Mycobacterium avium subsp. Paratubercolosis at a farm-scale biogas plant supplied with manure from paratuberculosis-affected dairy cattle. Appl Environ Microbiol 77:3115-3119. doi:10.1128/AEM. 02407-10

Smet E, Van Langenhore H, De Bo IZ (1998) The emission of volatile compounds during the aerobic and the combine anaerobic/aerobic composting of biowastes. Atmos Environ 33:1295-1303. doi:10. 1016/S1352-2310(98)00260-X

Snell-Castro R, Gordon JJ, Delgenes JP, Dabert P (2005) Characterisation of the microbial diversity in a pig manure storage pit using small subunit rDNA sequence analysis. FEMS Microbiol Ecol 52:229230. doi:10.1016/j.femsec.2004.11.016

Somasundaram E, Amanullahaiyapuri MM, Thirukkumaran K, Sathyamoorthi K (2007) Influence of organic sources of nutrients on the yield and economics of crops under maize based cropping system. J Appl Sci Res 3:1774-1777

Sommer SG, Hutchings NJ (2001) Ammonia emission from applied manure and its reduction - invited paper. Eur J Agron 15:1-15. doi:10.1016/S1161-0301(01)00112-5

Spencer JL, Guan J (2004) Public health implications related to spread of pathogens in manure from livestock and poultry operations. In: Spencer JFT, Ragout de Spencer AL (eds) Public health microbiology: methods and protocols. Humana, Totowa, pp 503-515

Stabnikova O, Goh WK, Ding HB, Tay JH, Wang JY (2005) The use of sewage sludge and horticultural waste to develop artificial soil for plant cultivation in Singapore. Bioresour Technol 96:1073-1080. doi:10.1016/j.biortech.2004.09.024

Sutka RL, Ostrom NE, Ostrom PH, Gandhi H, Breznak JA (2003) Nitrogen isotopomer site preference of $\mathrm{N}_{2} \mathrm{O}$ produced by Nitrosomonas europea and Methylococcus capsulatus Bath. Rapid Commun Mass Spectrom 17:738-745. doi:10.1002/rcm.968

Svensson K, Odlare M, Pell M (2004) The fertilizing effect of compost and biogas residues from source separated household waste. J Agric Sci 142:461-467. doi:10.1017/S0021859604004514

Svoboda N, Taube F, Wienforth B, Klu $\beta$ C, Kage H, Herrmann A (2013a) Nitrogen leaching losses after biogas residue application to maize. Soil Tillage Res 130:69-80. doi:10.1016/j.still.2013.02. 006

Svoboda N, Taube F, Wienforth B, Klu $\beta$ C, Wienforth B, Kage H, Ohl S, Hartung E, Herrmann A (2013b) Crop production for biomass and water protection. A trade-off? Agric Ecosyst Environ 177:36-47. doi:10.1016/j.agee.2013.05.024

Tambone F, Genevini P, D'Imporzano G, Adani F (2009) Assessing amendment properties of digestate by studying the organic matter composition and the degree of biological stability during the anaerobic digestion of the organic fraction of MSW. Bioresour Technol 100:3140-3142. doi:10.1016/j.biortech.2009.02.012

Tambone F, Scaglia B, D'Imporzano G, Schievano A, Salati V, Adani F (2010) Assessing amendment and fertilizing properties of digestates from anaerobic digestion through a comparative study with digested sludge and compost. Chemosphere 81:577-583. doi:10.1016/j. chemosphere .2010.08.034

Tang IN (1980) On the equilibrium partial pressure of nitric acid and ammonia in the atmosphere. Atmos Environ 14:819-828. doi:10. 1016/0004-6981(80)90138-9

Tang IN, Munkelwitz HR (1977) Aerosol growth studies III. Ammonium bisulfate aerosols in a moist atmosphere. J Aerosol Sci 8:321-330. doi:10.1016/0021-8502(77)90019-2
Tani M, Sakamoto N, Kishomoto T, Umetsu K (2006) Utilization of anaerobically digested slurry combined with other waste following application to agricultural land. Int Congr Ser 1293:331. doi:10. 1016/j.ics.2006.03.013

Teglia C, Tremier A, Martel JL (2011a) Characterization of solid digestates: part 1, review of existing indicators to assess solid digestates agricultural use. Waste Biomass Valor 2:43-58. doi:10. 1007/s12649-010-9051-5

Teglia C, Tremier A, Martel JL (2011b) Characterization of solid digestates: part 2, assessment of the quality and suitability for composting of six digested products. Waste Biomass Valor 2:113 126. doi:10.1007/s12649-010-9059-x

Terhoeven-Urselmans T, Scheller E, Raubuch M, Ludwig B, Joergensen $\mathrm{RG}$ (2009) $\mathrm{CO}_{2}$ evolution and $\mathrm{N}$ mineralization after biogas slurry application in the field and its yield effect on spring barley. Appl Soil Ecol 42:297-300. doi:10.1016/j.apsoil.2009.05.012

Thornton SF, McManus J (2002) Application of organic carbon and nitrogen stable isotope and $\mathrm{C} / \mathrm{N}$ ratios as source indicators of organic matter provenance in estuarine systems: evidence from the Tay Estuary, Scotland. Estuar Coast Shelf Sci 38:219-233. doi:10. 1006/ecss.1994.1015

Tietjen C (1975) From biodung to biogas - historical review of European experience. In: Jewell WJ (ed) Energy, agriculture, and waste management. Ann Arbor Science, Cornell, p 274

Tipping PJ (1996) Centralised anaerobic digestion: review of environmental effects. MAFF contract CSA 2730. MAFF, London

Tiquia SM, Tam NFY, Hodgkiss IJ (1996) Effects of composting on phytotoxicity of spent pig manure sawdust litter. Environ Pollut 93:249-256. doi:10.1016/S0269-7491(96)00052-8

Tiwari TN, Tiwari KN, Upadhyay RM (2000) Effect of crop residues and biogas slurry incorporation in wheat on yield and soil fertility. J Ind Soc Soil Sci 48:515-520

Vallejo A, Skiba UM, Garcia-Torres L, Arce A, Lopez-Fernandez S, Sanchez-Martin L (2006) Nitrous oxides emission from soil bearing a potato crop as influenced by fertilization with treated pig slurries and composts. Soil Biol Biochem 38:2782-2793. doi:10.1016/j. soilbio.2006.04.040

Van der Eerben LJM, de Visser PHB, van Dijk CJ (1998) Risk of damage to crops in the direct neighborhood of ammonia sources. Environ Pollut 102:49-53. doi:10.1016/S0269-7491(98)80014-6

Voća N, Kricka T, Cosic T, Rupic V, Jukic Z, Kalambura S (2005) Digested residues as a fertilizer after the mesophilic process of anaerobic digestion. Plant Soil Environ 51:262-266

Wachendorf M, Büchter M, Volkers K, Bobe J, Rave G, Loges R, Taube F (2006) Performance and environmental effects of forage production on sandy soils. V. Impact of grass understorey, slurry application and mineral $\mathrm{N}$ fertilizer on nitrate leaching under maize for silage. Grass Forage Sci 61:243-252. doi:10.1111/j.1365-2494.2006.00528.x

Wagner-Riddle C, Thurtell GW, Kidd GE, Beauchamp EG, Sweetman R (1997) Estimates of nitrous oxide emissions from agricultural fields over 28 months. Can J Soil Sci 77:135-144. doi:10.4141/S96-103

Warneck P (2000) Chemistry of the natural atmosphere, 2nd edn. Academic, New York

Watcharasukarn M, Kaparaju P, Steyer JP, Krogfelt KA, Angelidaki I (2009) Screening Escherichia coli, Enteroccocus faecalis, and Clostridium perfringens as indicator organisms in evaluating pathogen-reducing capacity in biogas plants. Microb Ecol 58:221230. doi:10.1007/s00248-009-9497-9

Weiland P (2010) Biogas production: current state and perspectives. Appl Microbiol Biotechnol 85:849-860. doi:10.1007/s00253-0092246-7

Wienhold BJ, Andrews SS, Karlen DL (2004) Soil quality: a review of the science and experiences in the USA. Environ Geochem Health 26:89-95. doi:10.1023/B:EGAH.0000039571.59640.3c

Williams JH, Guidi G, L'Hermite (1985) Long-term effects of sewage sludge and farm slurries applications. Elsevier, Barking 
Wong MH, Cheung YH, Cheung CL (1983) The effect of ammonia and ethylene oxide in animal manure and sewage sludge on the seed germination and root elongation of Brassica parachinensis. Environ Poll Ser A 30:109-123. doi:10.1016/0143-1471(83)90008-9

Wong JWC, Li GX, Wong MH (1996) The growth of Brassica chinensis in heavy metal-contaminated sewage sludge compost from Hong Kong. Bioresour Technol 58:309-313. doi:10.1016/S09608524(96)00121-6

Wrage N, Velthof GL, van Beusichem ML, Oenema O (2001) Role of nitrifier denitrification in the production of nitrous oxide. Soil Biol Biochem 33:1723-1732. doi:10.1016/S00380717(01)00096-7
Wulf S, Maeting M, Clemens J (2002a) Application technique and slurryco-fermentation effects on ammonia, nitrous oxide, and methane emissions after spreading: I. Ammonia volatilization. J Environ Qual 31:1789-1794. doi:10.2134/jeq2002.1789

Wulf S, Maeting M, Clemens J (2002b) Application technique and slurryco-fermentation effects on Ammonia, nitrous oxide, and methane emissions after spreading: II. Greenhouse gas emissions. J Environ Qual 31:1795-1801. doi:10.2134/jeq2002.1795

Zaoui R (1988) Valorga digestion process. In: Alston, YR, Richards GE (eds) Proceeding of international conference on landfill gas and anaerobic digestion of solid waste. Chester, England. Harwell Laboratory, UKAEA, Oxon. 0X11 ORA, pp 481-500 